\title{
Larval morphology and phylogenetic position of Drusus balcanicus, D. botosaneanui, D. serbicus and D. tenellus (Trichoptera: Limnephilidae: Drusinae)
}

\author{
Johann WARINGER 1 , Wolfram GRAF², Miklós BÁLINT ${ }^{3}$, Mladen KUČINIĆ4 ${ }^{4}$, StefFen U. PAULS ${ }^{3}$, \\ ANA PREVIŠIĆ ${ }^{4}$, LuIZA KERESZTES ${ }^{5}$, HALIL IBRAHIMI ${ }^{6}$, IVANA ŽIVIĆ ${ }^{7}$, KatARINA BJELANOVIĆ ${ }^{7}$, \\ VLADIMIR KRPAC̆ $^{8}$ and SIMON VITECEK ${ }^{1}$
}

\author{
${ }^{1}$ Department of Limnology and Oceanography, University of Vienna, Althanstrasse 14, A-1090 Vienna, Austria; \\ e-mails: johann.waringer@univie.ac.at; simon.vitecek@univie.ac.at \\ ${ }^{2}$ Institute of Hydrobiology and Aquatic Ecology Management, University of Natural Resources and Applied Life Sciences, Vienna, \\ Austria; e-mail: wolfram.graf@boku.ac.at \\ ${ }^{3}$ Biodiversity and Climate Research Centre (LOEWE BiK-F), Frankfurt a. M., Germany; e-mails: balint.miki@gmail.com; \\ Steffen.Pauls@senckenberg.de \\ ${ }^{4}$ Department of Biology, Faculty of Science, University of Zagreb, Croatia; e-mails: mladen.kucinic@zg.biol.pmf.hr; \\ ana.previsic@zg.biol.pmf.hr \\ ${ }^{5}$ Hungarian Department of Biology and Ecology, Babeş-Bolyai University, Cluj-Napoca, Romania; \\ e-mail: keresztes2012@gmail.com \\ ${ }^{6}$ Department of Biology, Faculty of Mathematics and Natural Sciences, University of Prishtina, Mother Theresa p. n., \\ 10000 Prishtina, Kosovo; e-mail: halilibrahimi@yahoo.com \\ ${ }^{7}$ Department of Zoology,University of Belgrade, Studentski trg 16, 11000 Belgrade, Serbia; e-mails: ivanas@bio.bg.ac.rs; \\ k.bjelanovic@bio.bg.ac.rs \\ ${ }^{8}$ National Institution Macedonian Museum of Natural History, Boulevard Ilinden 86, MK-91000 Skopje, Macedonia; \\ e-mail: vkrpach@gmail.com
}

Key words. Trichoptera, Limnephilidae, Drusinae, Drusus balcanicus, Drusus botosaneanui, Drusus serbicus, Drusus tenellus, 5th instar larvae, phylogeny, description, identification, distribution

\begin{abstract}
In a recent 3-gene phylogeny of the trichopteran subfamily Drusinae Banks 1916, molecular data clearly correlated with the morphology and feeding ecology of larvae. The largest of three main groups, the Drusinae grazer clade, exhibits an unusual larval feeding ecology for Limnephilidae, and is the most diverse group. In this paper we describe four previously unknown Drusinae larvae included in this clade: Drusus balcanicus Kumanski, 1973 (micro-endemic to Eastern Balkans), Drusus botosaneanui Kumanski, 1968 (Dinaric Western Balkans, Hellenic and Eastern Balkan, Asia Minor), Drusus serbicus Marinković-Gospodnetić, 1971 (micro-endemic to Dinaric Western Balkans), and Drusus tenellus (Klapálek, 1898) (Carpathians, Dinaric Eastern Balkans). Characteristically, the larvae of these species have toothless mandibles typical of the Drusinae grazer clade. Larvae and adults were unambiguously associated using a phylogenetic analysis based on two mitochondrial [mtCOI, mtLSU (=16S) rDNA] and two nuclear genes (nuWG, nuCAD). In addition, information on the morphology of the larvae is given and the diagnostic features necessary for identification are illustrated.
\end{abstract}

\section{INTRODUCTION}

Geographically the Drusinae Banks, 1916 are restricted to Eurasian mountain ranges from Iran and the Caucasus in the East to the Iberian Peninsula in the south-west. Three quarters of the known species are endemic to a single or very few mountain ranges, making the group an ideal model for studying evolutionary processes like speciation and diversification (Schmid, 1956; Kumanski, 1973; Marinković-Gospodnetić, 1971a, b, 1976; Sipahiler, 2002; Malicky, 2005). As cold-water adapted aquatic insects that occur as fragmented montane sky-island populations, Drusinae are also very sensitive to global change and their species are among the most threatened by climate warming. The taxon currently comprises eight genera (Drusus Stephens, 1837, Monocentra Rambur, 1842, Ecclisopteryx
Kolenati, 1848, Cryptothrix McLachlan, 1867, Metanoea McLachlan, 1880, Leptodrusus Schmid, 1955, Anomalopterygella Fischer, 1966, and Hadimina Sipahiler, 2002) and more than hundred species (Malicky, 2004, 2005; Graf et al., 2008; Kučinić et al., 2011a; Oláh, 2010, 2011; Oláh \& Kovács, 2013; Previšić et al., 2014). Unfortunately, larvae of only 45 species are described (references in Waringer et al., 2013a, b). In this paper we improve the knowledge of the larval taxonomy of Drusinae by presenting descriptions of the hitherto unknown larvae of Drusus balcanicus Kumanski, 1973, D. botosaneanui Kumanski, 1968, D. serbicus Marinković-Gospodnetić, 1971, and Drusus tenellus (Klapálek, 1898). The putative larvae of these four species were associated with co-occurring adults using molecular data from four gene regions and following the methods outlined by Pauls et al. (2006, 2008). 
TABLE 1. PCR primers and PCR cycling conditions.

\begin{tabular}{|c|c|c|c|c|c|}
\hline Fragment & Primers & $\begin{array}{c}\text { Primer } \\
\text { concentration }\end{array}$ & PCR cycling conditions & Taq Kit & $\begin{array}{c}\text { Additional } \\
\text { reagents }\end{array}$ \\
\hline $\begin{array}{l}\text { COI-5P } \\
\text { (barcode region) }\end{array}$ & HCOI, LCOI (Folmer et al., 1994) & $0.25 \mu \mathrm{M}$ & $\begin{array}{c}5^{\prime} 95^{\circ} \mathrm{C}, 5 \times\left(30^{\prime \prime} 95^{\circ} \mathrm{C}, 1^{\prime} 44^{\circ} \mathrm{C}, 1^{\prime} 72^{\circ} \mathrm{C}\right) \\
15 \times\left(30^{\prime \prime} 95^{\circ} \mathrm{C}, 30^{\prime \prime} 48^{\circ} \mathrm{C}, 1^{\prime} 72^{\circ} \mathrm{C}\right), \\
20 \times\left(30^{\prime \prime} 95^{\circ} \mathrm{C}, 30^{\prime \prime} 50^{\circ} \mathrm{C}, 1^{\prime}+\left(10^{\prime \prime} * \mathrm{n}\right) 72^{\circ} \mathrm{C}\right), 5^{\prime} 72^{\circ} \mathrm{C}\end{array}$ & peqGOLD HotTaq & - \\
\hline COI-3P & Jerry, S20 (Pauls et al., 2006) & $0.25 \mu \mathrm{M}$ & $5^{\prime} 95^{\circ} \mathrm{C} ; 35 \times\left(45^{\prime \prime} 95^{\circ} \mathrm{C}, 30^{\prime \prime} 45^{\circ} \mathrm{C}, 45^{\prime \prime} 72^{\circ} \mathrm{C}\right) ; 5^{\prime} 72^{\circ} \mathrm{C}$ & peqGOLD HotTaq & - \\
\hline 16SrDNA & Lepto-F, Lepto-R & $0.75 \mu \mathrm{M}$ & $3^{\prime} 5^{\circ} \mathrm{C}, 35 \times\left(30^{\prime \prime} 95^{\circ} \mathrm{C}, 30^{\prime \prime} 52^{\circ} \mathrm{C}, 40^{\prime \prime} 72^{\circ} \mathrm{C}\right), 5^{\prime} 72^{\circ} \mathrm{C}$ & peqGOLD HotTaq & $4 \mu \mathrm{g}$ BSA \\
\hline WG & $\begin{array}{l}\text { WGbDrrev 5'-ACCCTCTCCCGCARCACTTGAG-3' } \\
\text { WGbDrfwd 5'-CTTGCTGGATGCGTCTGCC-3' }\end{array}$ & $0.5 \mu \mathrm{M}$ & $5^{\prime} 95^{\circ} \mathrm{C}, 35 \times\left(45^{\prime \prime} 95^{\circ} \mathrm{C}, 45^{\prime \prime} 60^{\circ} \mathrm{C}, 90^{\prime \prime} 72^{\circ} \mathrm{C}\right), 7^{\prime} 72^{\circ} \mathrm{C}$ & $\begin{array}{l}\text { Qiagen Hotstar Taq } \\
\text { Plus Master mix }\end{array}$ & - \\
\hline CAD & 1028r-ino, 743nF-ino (Johanson \& Malm 2010) & $0.25 \mu \mathrm{M}$ & $5^{\prime} 95^{\circ} \mathrm{C}, 35 \times\left(45^{\prime \prime} 95^{\circ} \mathrm{C}, 30^{\prime \prime} 50^{\circ} \mathrm{C}, 45^{\prime \prime} 72^{\circ} \mathrm{C}\right), 5^{\prime} 72^{\circ} \mathrm{C}$ & peqGOLD HotTaq & - \\
\hline
\end{tabular}

As caddisfly larvae are important indicator taxa for monitoring water quality (Barbour et al., 1999; Barbour \& Yoder, 2000; AQEM consortium, 2002; Graf et al., 2002; Hering et al., 2006) and are frequently used as bioindicators (sensitive species) (Moog et al., 2002; Graf et al., 2002), the newly-described larvae will improve resolution of ecological assessment procedures. Further, larval morphology is also seen as an important tool in phylogenetics and taxonomy (van Emden, 1957; Meier \& Lim, 2009; Minoshima et al., 2013). The descriptions of the four new Drusinae larvae will, therefore, also increase our present knowledge of the phylogenetic structure of the Drusinae grazer clade sensu Pauls et al. (2008).

\section{MATERIAL AND METHODS}

\section{Species collection}

Adults and larvae of Drusus serbicus, D. botosaneanui, D. balcanicus, and D. tenellus were collected by hand on the Balkan Peninsula (for locations see Material examined).

The material intended for sequencing was placed in pure $96 \%$ alcohol and that for morphological analyses in pure $70 \%$ ethanol in order to keep the specimens more flexible.

\section{Morphological study}

Morphological terminology, including setal nomenclature, follows Wiggins (1998). The larvae were described in terms of the set of morphological characters for Drusinae defined by Waringer \& Graf (2011). Larvae were studied and photographed using a Nikon SMZ 1500 binocular microscope with DS-Fil camera and NIS-elements D 3.1 image stacking software, which combine 8 to 42 frames in one focused image. The two 5 th instar larvae of $D$. balcanicus and the three larvae of $D$. botosaneanui, D. serbicus and D. tenellus are deposited in the collection of J. Waringer (Vienna, Austria).

For SEM microscopy, two fifth instar larvae of Drusus serbicus were air dried, gold coated using a BAL-TEC SCD 005 sputter coater and examined using a JEOL JSM-6390lv scanning electron microscope.

Comparative material of other Drusinae species included the following (all larvae preserved in pure 70\% ethanol): Drusus franzressli Malicky, 1974 (two 5th instar larvae), D. spelaeus (Ulmer, 1920) (five 5th instar larvae), D. schmidi Botosaneanu,
1960 (six 5th instar larvae), D. improvisus (McLachlan, 1884) (eight 5th instar larvae), D. nigrescens Meyer-Dür, 1875 (five 5th instar larvae), D. rectus McLachlan,1868 (six 5th instar larvae), D. brunneus Klapálek, 1898 (one 5th instar larva), D. bosnicus Klapálek, 1899 (one 5th instar larva), D. radovanovici Marinković-Gospodnetić, 1971 (one 5th instar larva), D. septentrionis Marinković-Gospodnetić, 1976 (two 5th instar larvae), D. trifidus McLachlan, 1868 (three 5th instar larvae), Ecclisopteryx dalecarlica Kolenati, 1848 (one 5th instar larva), E. guttulata (Pictet, 1834) (three 5th instar larvae), E. madida (McLachlan,1867) (one 5th instar larva), Hadimina torosensis Sipahiler, 2002 (one 5th instar larva), Metanoea rhaetica Schmid, 1956 (seven 5th instar larvae), and M. flavipennis (Pictet, 1834) (ten 5 th instar larvae). This material is deposited in the collection of $\mathrm{J}$. Waringer (Vienna, Austria).

\section{Molecular study}

We used phylogenetic analysis to associate the larvae. We inferred phylogenetic trees based on molecular sequence data from two nuclear and two mitochondrial genes of the four target species and those previously published for 43 other species of Drusinae (Supplementary table S1). We extracted DNA from larval and adult specimens using the DNEasy Blood \& Tissue Kit (Qiagen) following the manufacturer's protocol. PCRs were carried out in $10 \mu \mathrm{l}$ of solution. PCR procedures and primers are listed in Table 1. PCR products were sequenced on an ABI 3177XL capillary sequencer at the Biodiversity and Climate Research Laboratory Centre. Sequences were edited in Geneious vR7 (biomatters). Sequences were aligned using the Muscle-plugin in Geneious vR7.

We inferred phylogenetic trees for each locus separately using a Bayesian/MCMC analysis implemented in MrBayes v3.2.1 (Ronquist et al., 2012). Nucleotide substitution models were selected using the Bayesian Information Criterion in the model test module of MEGA v5.2 (Tamura et al., 2011). In the protein coding genes, nucleotide substitution models were identified separately for each codon position (see Table 2 for codon-specific selected models). We did not partition the 16SrDNA fragment. All model estimations were performed using all sites, i.e. including the gaps in LSU. The B/MCMC analysis was based on 2 parallel runs with six chains each that explored tree space for 10 million generations. Phylogenetic trees were based on 15,000 trees $(2 \times$ 7,500 ) following a $25 \%$ burn-in phase. We assessed the parameter files in Tracer Version 1.4.6 (Drummond \& Rambaut, 2007) to determine if each run had reached stationarity. We used the

TABLE 2. Characteristics of the molecular data sets used in the phylogenetic analysis and larval-adult associations.

\begin{tabular}{lccccc}
\hline Locus & $\begin{array}{c}N \\
\text { sequences }\end{array}$ & $\begin{array}{c}\text { Length } \\
(\mathrm{bp})\end{array}$ & $\begin{array}{c}\text { Variable sites } \\
(N / \%)\end{array}$ & $\begin{array}{c}\text { Substitution model by codon } \\
\text { position }\left(1^{\text {st }} / 2^{\text {nd }} / 3^{\text {rd }}\right)\end{array}$ & $\begin{array}{c}\text { Average standard deviation of split frequencies } \\
\text { after } 25 \text { mio \& } 100 \text { mio generations }\end{array}$ \\
\hline $\mathrm{COI}$ & 187 & $1210^{*}$ & $533 / 44$ & $\mathrm{TN} 93+\mathrm{G} / \mathrm{HKY}+\mathrm{G} / \mathrm{GTR}+\mathrm{I}+\mathrm{G}$ & $0.014-0.007$ \\
$\mathrm{LSU}$ & 197 & 362 & $162 / 44$ & $\mathrm{~T} 92+\mathrm{G}$ & $0.011-0.005$ \\
$\mathrm{CAD}$ & 163 & 848 & $644 / 76$ & $\mathrm{HKY}+\mathrm{G} / \mathrm{HKY} / \mathrm{K} 2+\mathrm{G}$ & $0.008-0.004$ \\
$\mathrm{WG}$ & 181 & 352 & $147 / 42$ & $\mathrm{JC}+\mathrm{G} / \mathrm{JC} / \mathrm{T} 92$ & $0.008-0.005$ \\
\hline
\end{tabular}

* 11 Ns were added between the two fragments of mtCOI. 
TABLE 3. Results of larval associations based on phylogenetic reconstruction for each of the four loci. The 5th instar larvae of the target species are deposited in the collection of J. Waringer (Vienna, Austria). $\mathrm{m}$ - males, $\mathrm{f}$ - females, 1 - larvae, pp - posterior probability.

\begin{tabular}{|c|c|c|c|c|c|c|c|c|c|c|c|c|}
\hline \multirow[b]{2}{*}{ Species } & \multicolumn{3}{|c|}{ CAD } & \multicolumn{3}{|c|}{$\mathrm{COI}$} & \multicolumn{3}{|c|}{ WG } & \multicolumn{3}{|c|}{ LSU } \\
\hline & $\mathrm{pp}$ & $\begin{array}{c}\text { Association } \\
\text { criterion }\end{array}$ & $\begin{array}{c}N \\
(\mathrm{~m} / \mathrm{f} / \mathrm{l}) \\
\end{array}$ & $\mathrm{pp}$ & $\begin{array}{c}\text { Association } \\
\text { criterion }\end{array}$ & $\begin{array}{c}N \\
(\mathrm{~m} / \mathrm{f} / \mathrm{l}) \\
\end{array}$ & $\mathrm{pp}$ & $\begin{array}{c}\text { Association } \\
\text { criterion }\end{array}$ & $\begin{array}{c}N \\
(\mathrm{~m} / \mathrm{f} / \mathrm{l}) \\
\end{array}$ & $\mathrm{pp}$ & $\begin{array}{c}\text { Association } \\
\text { criterion }\end{array}$ & $\begin{array}{c}N \\
(\mathrm{~m} / \mathrm{f} / 1)\end{array}$ \\
\hline D. serbicus & 1.0 & $\begin{array}{c}\text { monophyly; } \\
\text { identical haplotypes }\end{array}$ & $4 / 1 / 2$ & 1.0 & $\begin{array}{c}\text { monophyly; } \\
\text { identical haplotypes }\end{array}$ & $4 / 1 / 2$ & 0.98 & $\begin{array}{c}\text { monophyly; } \\
\text { identical haplotypes }\end{array}$ & $4 / 1 / 2$ & 0.99 & identical haplotypes & $4 / 1 / 2$ \\
\hline D. tenellus & 1.0 & monophyly & $1 / 1 / 1$ & 1.0 & monophyly & $1 / 1 / 2$ & 1.0 & sister clades & $1 / 1 / 2$ & $0.98^{\mathrm{r}}$ & $\begin{array}{c}\text { nonophyly (by exclusion } \\
\text { to } D \text {. botosaneanui) }\end{array}$ & $1 / 1 / 2$ \\
\hline D. botosaneanui & 1.0 & $\begin{array}{l}\text { monophyly; larvae } \\
\text { nested within males }\end{array}$ & $3 / 0 / 7$ & 1.0 & monophyly & $3 / 1 / 3$ & 0.89 & $\begin{array}{l}\text { monophyly; } \\
\text { identical haplotype to } 9\end{array}$ & $0 / 1 / 4$ & 1.0 & identical haplotype & $3 / 1 / 4$ \\
\hline D. balcanicus & 1.0 & $\begin{array}{c}\text { monophyly; } \\
\text { identical haplotypes }\end{array}$ & $5 / 0 / 2$ & 0.9 & $\begin{array}{c}\text { monophyly; } \\
\text { identical haplotypes }\end{array}$ & $6 / 1 / 2$ & 0.82 & identical haplotypes & $6 / 1 / 2$ & 0.97 & identical haplotype & $6 / 1 / 2$ \\
\hline
\end{tabular}

average standard deviation of split frequencies between runs after 2,500,000 generations if both runs reached the same optimality space.

\section{RESULTS}

\section{Identification of the larvae}

The putative conspecific larvae always clustered in monospecific clades with adults (Table 3, supplementary Figs S2a-d). There are, however, some weaknesses in the resolution of the larval association clades. In the WG phylogeny, clades including $D$. botosaneanui and D. balcanicus were not significantly supported ( $\mathrm{pp}<0.95)$. For COI and CAD all sequences of D. balcanicus are basal to a highly supported clade for $D$. discophoroides Kumanski, 1979 ( $\mathrm{pp}=1.0$ ), but are not grouped in supported clades. For LSU there is a similar situation regarding $D$. tenellus. However, these topological inconsistencies only insignificantly weaken the overall associations of adults with larvae, which are further supported by identical haplotypes in all species except $D$. tenellus.

\section{Drusus serbicus Marinković-Gospodnetić, 1971a}

Material examined. 3 ex. of fifth instar, Golija Mt, spring Ilinac (Serbia), 43 $20^{\circ} 00^{\prime \prime} \mathrm{N}, 20^{\circ} 16^{\prime} 55^{\prime \prime} \mathrm{E}, 1500 \mathrm{~m}$ a.s.1., 22 June 2013, leg. Kučinić, Bjelanović, Živić.

General morphology. Larva eruciform, head and sclerotized parts chestnut to blackish brown, nonsclerotised parts whitish. Body length 9.8-10.8 mm, head width 1.33$1.43 \mathrm{~mm}$.

Head. Head capsule coarsely granulated, almost circular in shape and hypognathous (Figs 1A-C), dorsally with blackish muscle attachment spots. Ventral parietalia sections, submentum, maxillolabial sclerites and premandibular areas medium to orange brown (Figs 1C, D). Yellowishwhite ring around each eye (Fig. 1C). In lateral view, head capsule with carina $(0.40-0.45 \mathrm{~mm}$ long and approximately $0.04 \mathrm{~mm}$ wide) starting a short distance from anterior margin of eye and extending to frontomedian corner of frontoclypeus (Fig. 1C, arrow).

Head capsule with complete set of 18 pairs of primary setae and lacking any additional spines or bristles known to occur in other Drusinae larvae (e.g., Ecclisopteryx spp., Drusus trifidus). However, posterior to each eye, there is a spinule area surrounding the bases of setae 15 and 16 (diameter 0.13-0.18 mm; Figs 1E, F; white ovals). Such spinule areas occur in most members of the Drusus bosnicus Group sensu Marinković-Gospodnetić (1971a), e.g.,
Drusus klapaleki Marinković-Gospodnetić, 1971b. Frontoclypeus bell-shaped, with narrow central constriction (Figs 1A, B).

Antennae arise on dorsal rim of lateral carina and halfway between eye and anterior head margin (Fig. 1E, arrow), each consisting of 1 short cylindrical base and 1 short flagellum. On each parietale there are 10 dorsal and 2 ventral primary setae, with primary setae 5, 9 and 14 long and conspicuous (Figs 1B, C, E). Six primary setae on each side of frontoclypeus, 3 of them along anterior border. Labrum medium to light brown, with setal brush and primary setae 1-3 on anterolateral margins; on dorsal area, setation consists of primary setae 4-6 (Figs 1A, E).

Ventral apotome elongated triangular, medium to light brown, postgenal suture approximately $55 \%$ of apotome length (Fig. 1D). Blackish brown to dark brown mandibles lacking terminal teeth along edges as well as lacking ridges in central concavity (Figs 1D, E).

Thorax. Pronotum black brown to chestnut brown, very coarsely granulated (Figs 1C, 2A, B); its posterior margin thickened and darkly striped (Fig. 2C). Pronotal transverse groove on end of anterior third lacking. Dorsal profile in lateral view with annular crest highest at dorsal centre and gradually declining laterally (Figs $2 \mathrm{~B}, \mathrm{C}$ ). With semicircular step between crest centre and posterior pronotal rim (Fig. 2A, between arrows). In anterior view, pronotal crest with a dorsocentral notch (Fig. 1A, black arrow). Two setal rows along anterior border of pronotum: (1) Dense fringe of short, curved, fine, yellow setae; (2) continuous row of long, widely-spaced, straight, dark setae meeting on anterior pronotal midline (Figs 2A, B); in total, 80-90 dark setae of varying lengths distributed over each pronotal half (Figs 1C, 2A, C). In addition, pronotal surface covered by high number of tiny, pale, recumbent setae (Fig. 2D); spines present in some other Drusinae (e.g., Ecclisopteryx dalecarlica) are absent. Pentangular prosternite light brown with medium brown posterior rim; prosternal horn present.

Mesonotum completely covered by 2 medium to yellowish brown sclerites with fine granulation except along posterior border and on lateral half of anterior border; their lateral and posterior margins with black sclerotization (Fig. 2E). Counts for mesonotal setae are as follows: Anterior setal group $s a 1$ : 15-18, posterior group $s a 2$ : 15-20, lateral group sa3: 28-30.

Metanotum partially covered by 3 pairs of medium to dark brown sclerites. Anterior metanotal sclerites ( $s a 1)$ 

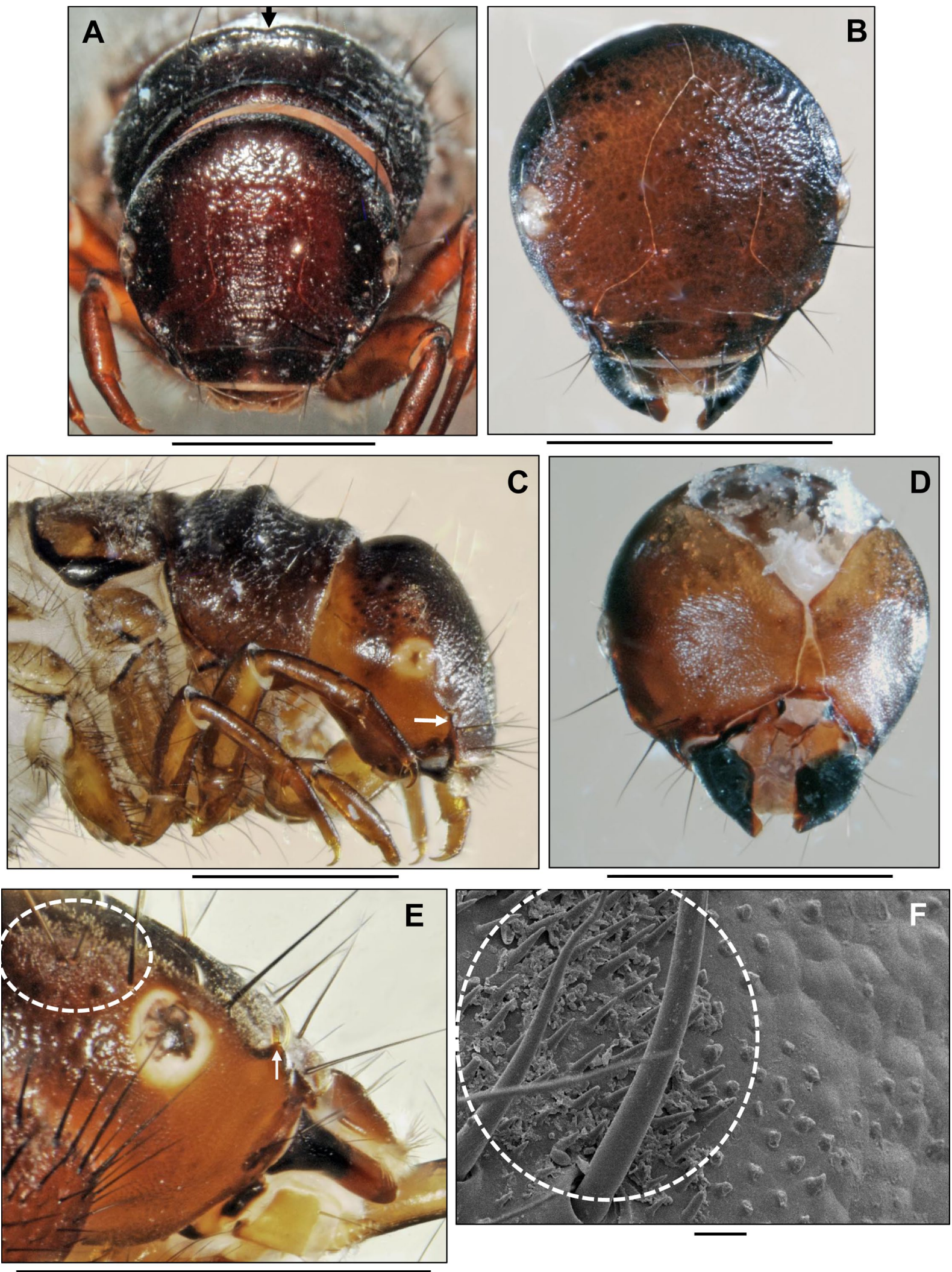

Fig. 1. Drusus serbicus (5th instar larva). A - head and pronotum, frontal view (arrow: median notch); B - head, frontal view; C head, pro- and mesothorax, right lateral view (arrow: lateral carina); D - head, ventral view; E-F - head, dorsolateral view, details of spinule area (white ovals) (arrow in E: antenna). Scale bars: $\mathrm{A}-\mathrm{E}=1 \mathrm{~mm} ; \mathrm{F}=0.02 \mathrm{~mm}$.

very large, broadly ovoid, strongly tapering laterally, each with black anterior margin; separated by less than own length (Fig. 2E). Approximately 15 setae per sclerite (Fig. 2E). Row of setae present between small posteromedian sclerites ( $s a 2$ ); each sclerite bears 14-17 setae. Small setal group present between each lateral ( $\mathrm{sa} 3$ ) and posteromedian sclerite ( $s a 2$ ); each $s a 3$ with approximately 25-30 setae, concentrated anteriorly (Fig. 2E). Legs orange brown with 

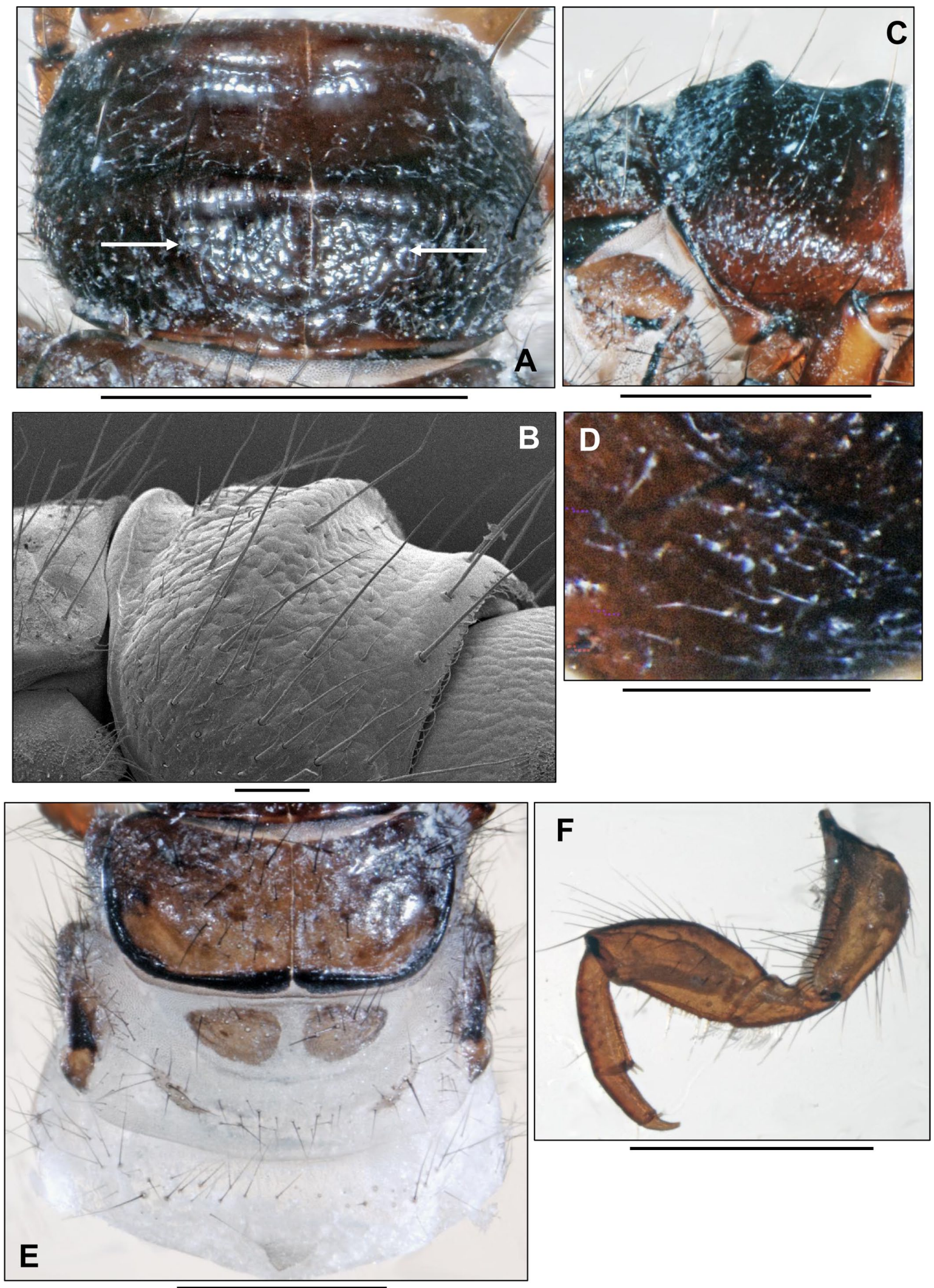

Fig. 2. Drusus serbicus (5th instar larva). A-C - pronotum, dorsal and right lateral view (arrows: semicircular step posterior of pronotal annular crest); D - pronotum, central posterior region, showing white recumbent setae; $\mathrm{E}$ - mesonotum, metanotum and 1st abdominal segment, dorsal view; $\mathrm{F}$ - left fore leg, posterior view. Scale bars: A, C, E-F = $1 \mathrm{~mm} ; \mathrm{B}=0.2 \mathrm{~mm} ; \mathrm{D}=0.5 \mathrm{~mm}$.

setae numerous on coxae, trochanters and femora, sparse on tibiae and tarsi (Figs 2F, 3A, B). All femora with several proximodorsal setae. Coxa, femur and tibia of each foreleg wider than those of mid- and hind legs. Setae present on proximal parts of trochanters of all three pairs of legs. Additional setae present on both anterior and posterior faces 

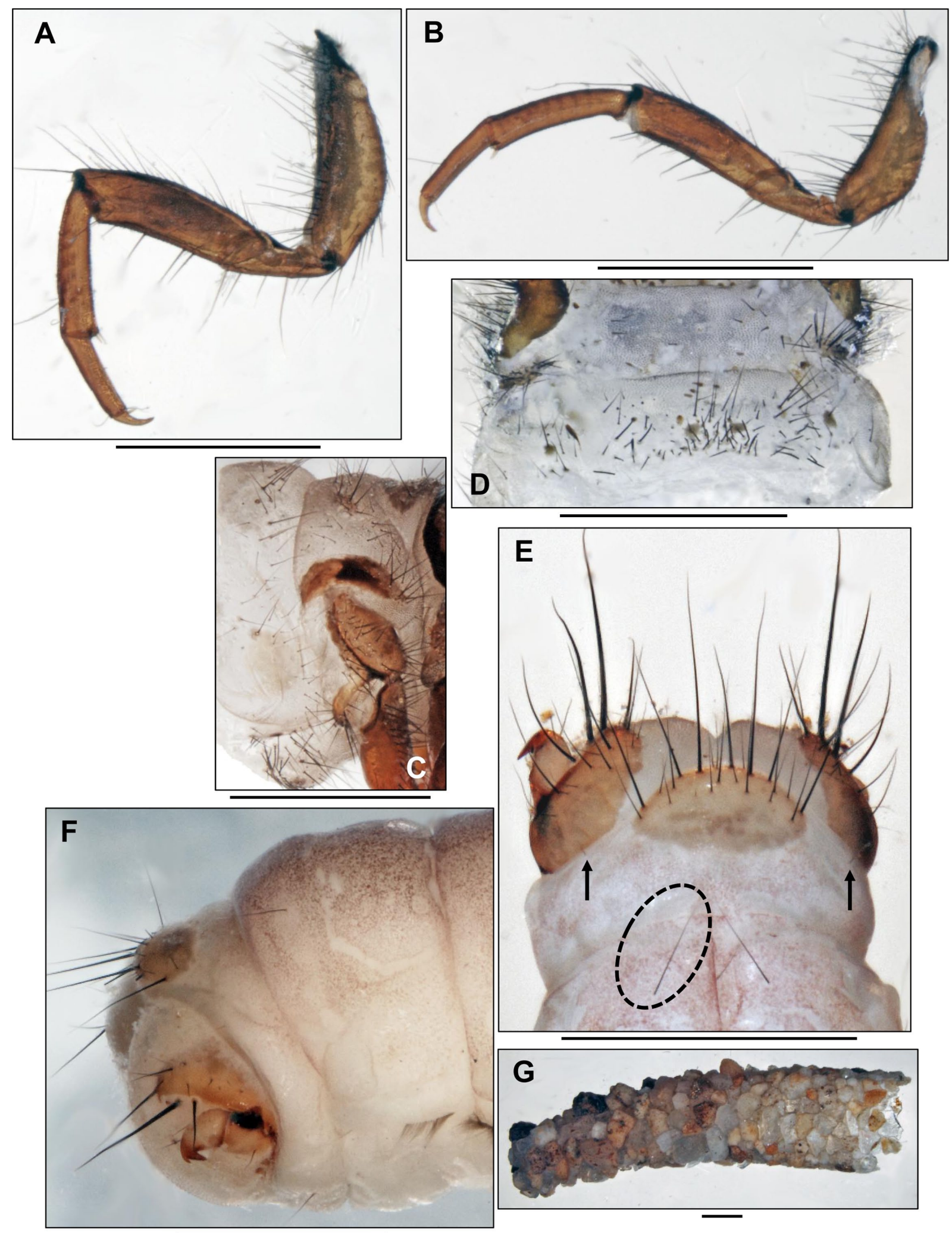

Fig. 3. Drusus serbicus (5th instar larva). A - left mid leg, posterior view; B - left hind leg, posterior view; $\mathrm{C}-$ metathorax and 1st abdominal segment, right lateral view; D - 1st abdominal sternum; E - abdominal segments VIII-IX, dorsal view (arrows: posterolateral setae; dotted oval: posterodorsal setae); F - apex of abdomen, right lateral view; $\mathrm{G}$ - case, right lateral view. Scale bars: $\mathrm{A}-\mathrm{G}=1 \mathrm{~mm}$.

of all femora; ventral trochanteral brush present on fore and mid leg. Ventral edges of fore femora each with 5 yellow setae, of mid- and hind femora each with 4 dark setae. Dorsal setae only on distal third of mid and hind tibiae (Figs 2F, 3A, B).
Abdomen. First abdominal segment with 1 dorsal and 2 lateral fleshy protuberances (Figs 2E, 3C). Dorsal setal areas $s a 1, s a 2$ and $s a 3$ fused, thereby creating continuous transverse row of setae anterior to dorsal protuberance, which extends to the dorsal section of each lateral protu- 

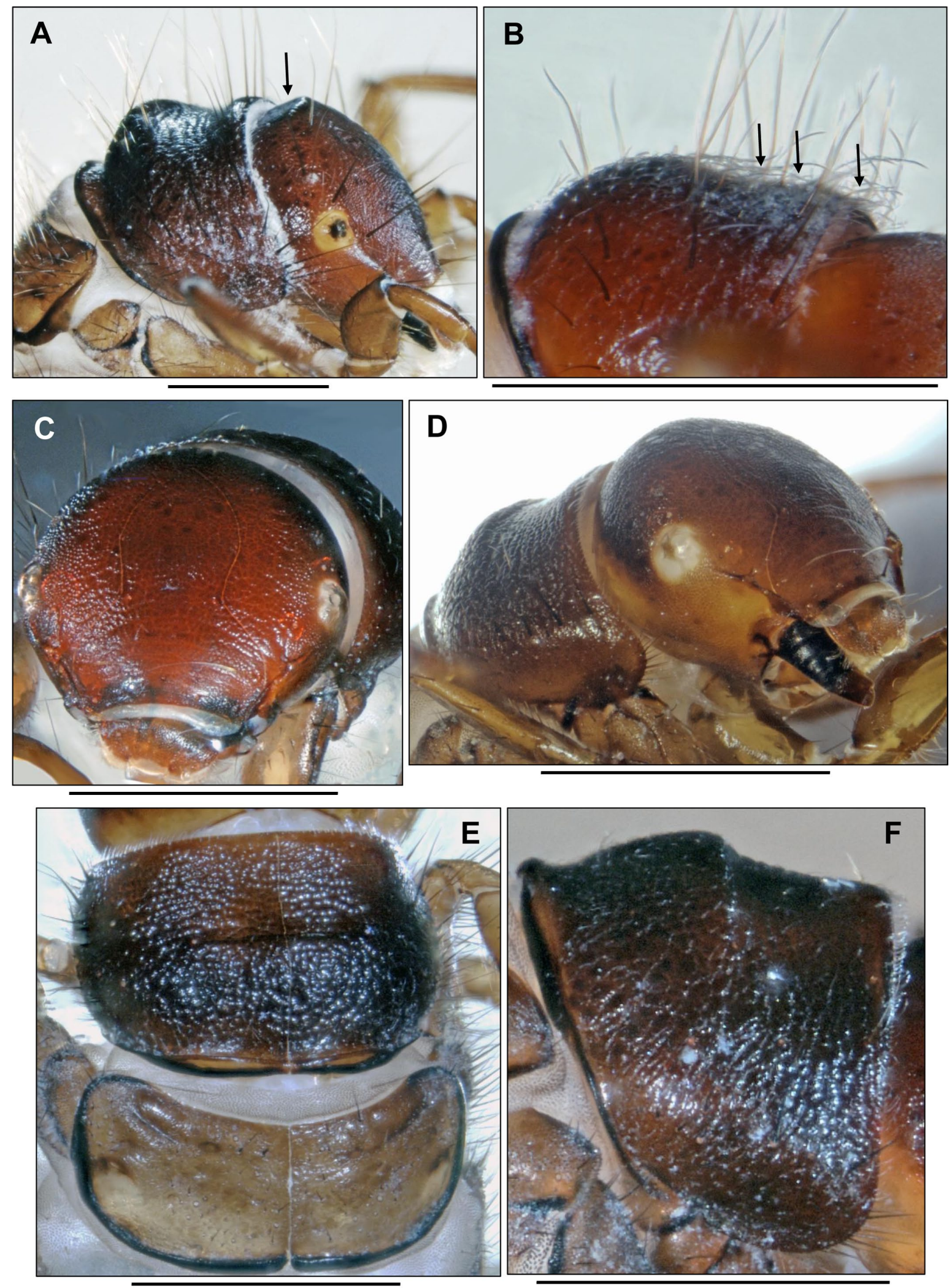

Fig. 4. A - Drusus bosnicus (5th instar larva), head and pronotum, right lateral view (arrow: vertex flattened); B - Drusus radovanovici (5th instar larva), pronotum, right lateral view (arrows: thin long yellowish setae); C-F - Drusus balcanicus (5th instar larva): $\mathrm{C}$ - head, frontal view; D - head and pronotum, right anterolateral view; E - pro- and mesonotum, dorsal view; F - pronotum, right lateral view. Scale bars: A-F $=1 \mathrm{~mm}$.

berance. Sharply delimited basal sclerites present in about $30 \%$ of these setae; without setal group posterior to dorsal protuberance (Fig. 2E). Lateral protuberances lacking pos- terior sclerites (Fig. 3C). A continuous band of anterolateral setae present in front of each lateral protuberance, linking each dorsal and ventral sa3 setal group (Fig. 3C). First 

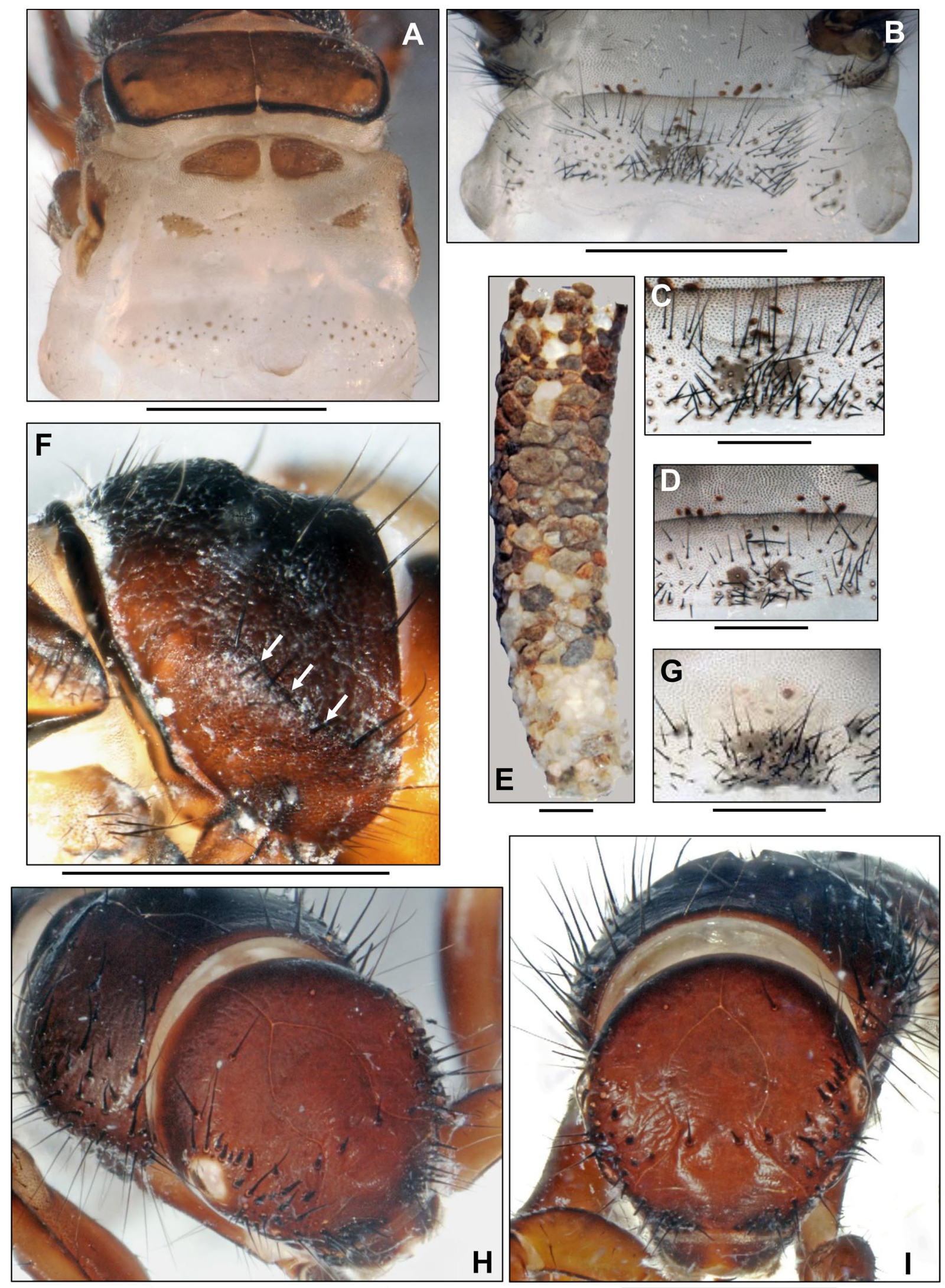

Fig. 5. A-E - Drusus balcanicus (5th instar larva): A - mesonotum, metanotum and 1st abdominal dorsum, dorsal view; B - 1st abdominal sternum, ventral view; C,D - details of central areas of 1st abdominal sternum, ventral view; E - case, right lateral view. F, G - Drusus franzressli (5th instar larva): $\mathrm{F}$ - pronotum, right lateral view (arrows: lateral ridge); $\mathrm{G}$ - detail of central area of 1st abdominal sternum, ventral view. H, I - Drusus botosaneanui (5th instar larva): H - head and pronotum, dorsolateral view; I - head and pronotum, frontal view. Scale bars: A, B, E, F, H, I = $1 \mathrm{~mm} ; \mathrm{C}, \mathrm{D}, \mathrm{G}=0.3 \mathrm{~mm}$. 

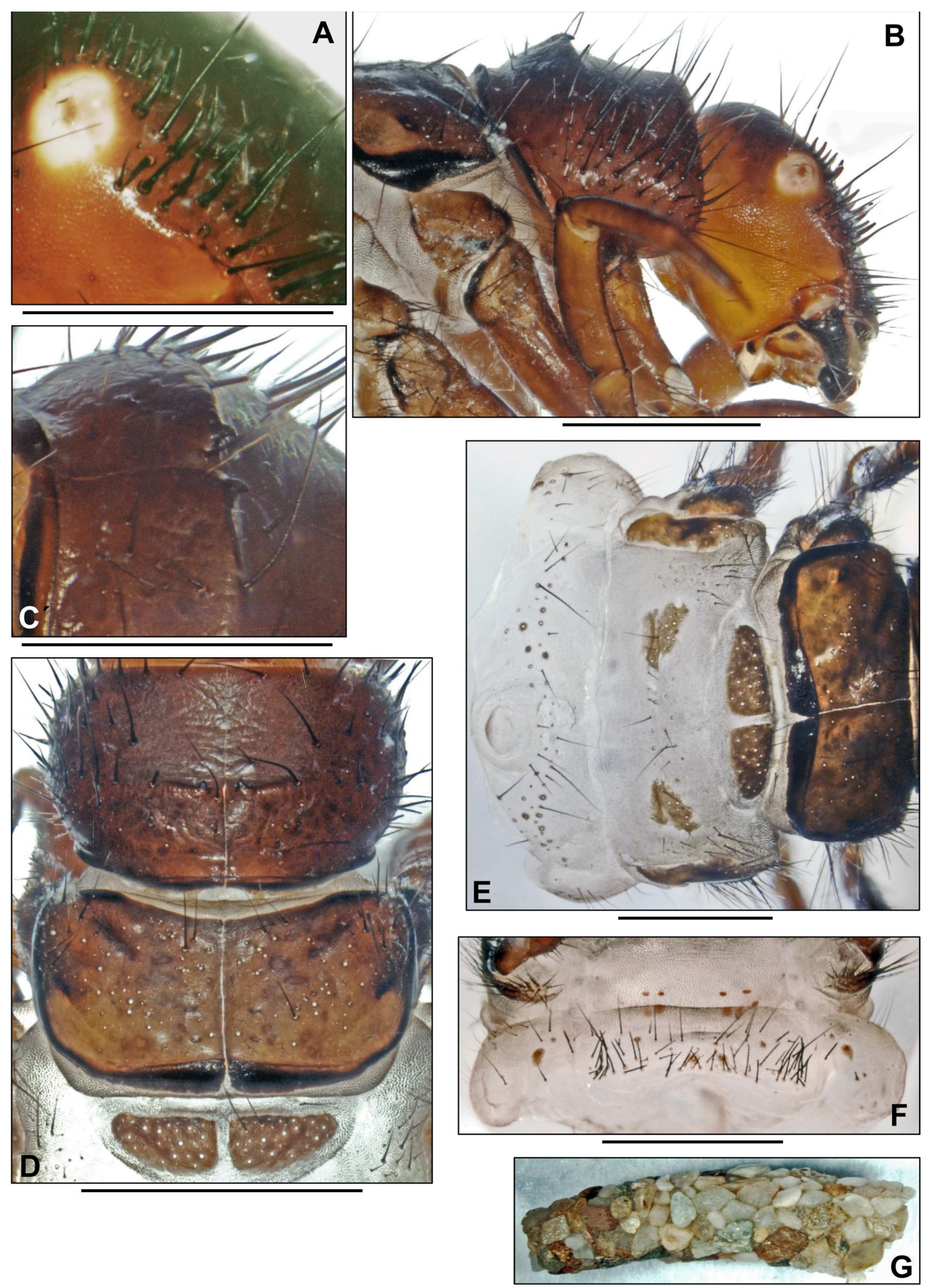

Fig. 6. Drusus botosaneanui (5th instar larva). A - head, detail of spines and bristles on right parietale; B - head, pro- and mesonotum, right lateral view; $\mathrm{C}$ - detail of central ridge on pronotum showing median notch flanked by anteriorly directed hooks; D - pronotum, mesonotum and anterior part of metanotum, dorsal view; $\mathrm{E}$ - mesonotum, metanotum and 1st abdominal segment, dorsal view; $\mathrm{F}-1$ st abdominal sternum, ventral view; $\mathrm{G}$ - case, right lateral view. Scale bars: $B, D-G=1 \mathrm{~mm} ; \mathrm{A}, \mathrm{C}=0.5 \mathrm{~mm}$. 
abdominal sternum with ventral setal areas $s a 1, s a 2$ and $s a 3$ fused, creating continuous field of setae; basal sclerites of setae on the central area of the first abdominal sternum mostly small and inconspicuous except for four larger basal sclerites near midline and immediately ventral to the lateral protuberances. Basal sclerites never fuse with one another (Fig. 3D). Eighth abdominal dorsum bears two to four long posterodorsal setae (pds) (Fig. 3E, dotted oval). Only 1 posterolateral seta present on each half of 9th abdominal dorsum (Fig. 3E, arrows).

All gills single filaments. Dorsal gills present at most on the 2nd (presegmental position) to the 7 th segment (presegmental position). Ventral gills on the 2nd (postsegmental) to 8th segment (presegmental). Lateral gills lacking. Lateral fringe extending from posterior third of 2 nd to middle of 8th abdominal segment; in addition, a prominent seta surrounded by a small number of isolated lateral fringe setae on anterior border of 2 nd segment. Light brown sclerite on 9th abdominal tergum semicircular (Fig. 3E); 7-8 long and several shorter setae present along its posterior border, 1-2 of the long setae take the position of central intermediate $c$ setae (Fig. 3E). Anal prolegs of limnephilid type, light to medium brown, with light muscle attachment spots. Anal claws medium brown, each with 1 small accessory hook (Fig. 3F).

Case. Larval case 10.2-10.5 mm long $(\mathrm{n}=3)$, curved, conical (width at anterior opening 2.45-2.7 $\mathrm{mm}$ and at posterior opening 1.7-2.3 mm), consisting of mineral particles (sand grains of mixed sizes; Fig. 3G).

Habitat. This species inhabits the epirhithral section of oxygen-rich streams with high to moderate currents, but is also encountered near the source (hypocrenal region) down to the metarhithral zone. Drusus serbicus is a grazer feeding on epilithic biofilms and associated algae.

\section{Key to larvae of species of Drusus of the grazer clade having spinule areas on head capsules}

As in the other species in the Drusinae grazer clade, the mandibles are spoon-shaped (lack terminal teeth and ridges in central cavity; Fig. 1E). The larva of Drusus serbicus is similar to six Drusinae species from the Balkan Peninsula, which have a small field of spinules (= small spines approximately $0.03 \mathrm{~mm}$ long) posterior to their eyes (Figs 1E, F). Based on the recent detailed descriptions of Kučinić et al. (2008, 2010, 2011a, b, in press) and unpublished data of Previšić et al., D. serbicus is integrated into the following dichotomous key:

1 Head with flat vertex (Fig. 4A)... Drusus bosnicus Klapálek, 1899

- Vertex evenly rounded (e.g., Fig. 1C) .................................. 2

2 Pronotum with thin, long, yellow setae (Fig. 4B) Drusus radovanovici Marinković-Gospodnetić, 1971b Pronotum without thin, long, yellow setae ............................. 3

3 Pronotum with numerous short, white, recumbent setae (Fig.

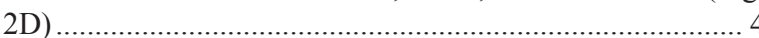
- Pronotum without numerous short, white, recumbent setae... Drusus septentrionis Marinković-Gospodnetić, 1976

4 Dorsal pronotal hump smoothly rounded... Drusus medianus Marinković-Gospodnetić, 1976
- Dorsal pronotal hump with distinct ridge (e.g., Fig. 2 A-C)..

Anterior metanotal sclerites elongate and triangular (width

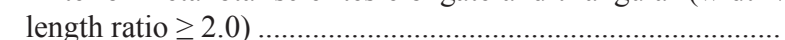
............. Drusus vespertinus Marinković-Gospodnetić, 1976 - Anterior metanotal sclerites broadly triangular (width / length ratio $<2.0$; e.g., Fig. 2E)....

6 In lateral view, posterior side of dorsal ridge gently descends Drusus klapaleki Marinković-Gospodnetić, 1971b In lateral view, dorsal ridge annular, posterior side sharply descending (Figs 2A-C).

..Drusus serbicus Marinković-Gospodnetić, 1971a

\section{Drusus balcanicus Kumanski, 1973}

Material examined. 2 ex. of fifth instar, Troyan Pass brook, south side (Bulgaria), $42^{\circ} 47^{\prime} 21^{\prime \prime} \mathrm{N}, 24^{\circ} 37^{\prime} 05^{\prime \prime} \mathrm{E}, 1450 \mathrm{~m}$ a.s.1., 12 June 2013, leg. Keresztes, Torok, Kolocsar.

General morphology. Larva eruciform, head and sclerotized parts dark brown, nonsclerotised parts whitish. Body length 11.0-11.2 mm, head width 1.27-1.30 mm.

Head. Head capsule granulated, roundish (Figs 4C, D). Labrum dark brown, with setal brush (Fig. 4D). Ventral apotome yellowish to light brown and with postgenal suture approximately $70-75 \%$ of apotome length. Head capsule lacking any additional spines, bristles or areas of spinules.

Thorax. Pronotum with adjacent series of granuli creating ribbed structures (Fig. 4F). Dorsal profile in lateral view with posterior half of pronotum rounded, this curvature creates a distinct step leading down to anterior, lower part of pronotum (Fig. 4F). Lateral ridge lacking. In total, 35-40 dark setae of varying lengths distributed over each pronotal half. Prosternite very light and indistinct.

Mesonotum completely covered by 2 medium brown to yellowish sclerites with dark brown muscle attachment spots (Fig. 4E). Their anterolateral corners, lateral and posterior margins darkly sclerotized. Number of setae in anterior setal group $s a 130-40$, in posterior group $s a 2$ 25-30 and in lateral group sa3 25-30.

Anterior $s a 1$ metanotal sclerites triangular, with approximately 25-30 setae per sclerite (Fig. 5A). Setal counts for both posteromedian $s a 2$ sclerites and lateral sa3 sclerites are 15-20 setae per sclerite. Legs light brown. All other details as in D. serbicus.

Abdomen. Centre of 1st abdominal sternum with large or medium concentrations of fused basal sclerites of setae, creating multilobed patterns of sclerotized areas positioned mostly posterior of the two largest basal sclerites (Figs 5B-D).

Dorsal gills present at most on 2nd (presegmental position) to the 5th segment (presegmental position). Ventral gills on the 2 nd (presegmental) to 7 th segment (presegmental). Lateral gills lacking. Lateral fringe, details of 9th abdominal sclerite and of anal prolegs as in D. serbicus.

Case. Larval case 10.6-10.7 mm long $(\mathrm{n}=2)$, curved, slightly conical. Width at anterior opening $2.5-2.6 \mathrm{~mm}$ and at posterior opening $1.8-1.9 \mathrm{~mm}$, consisting of mineral particles (sand grains of mixed size; Fig. 5E). 

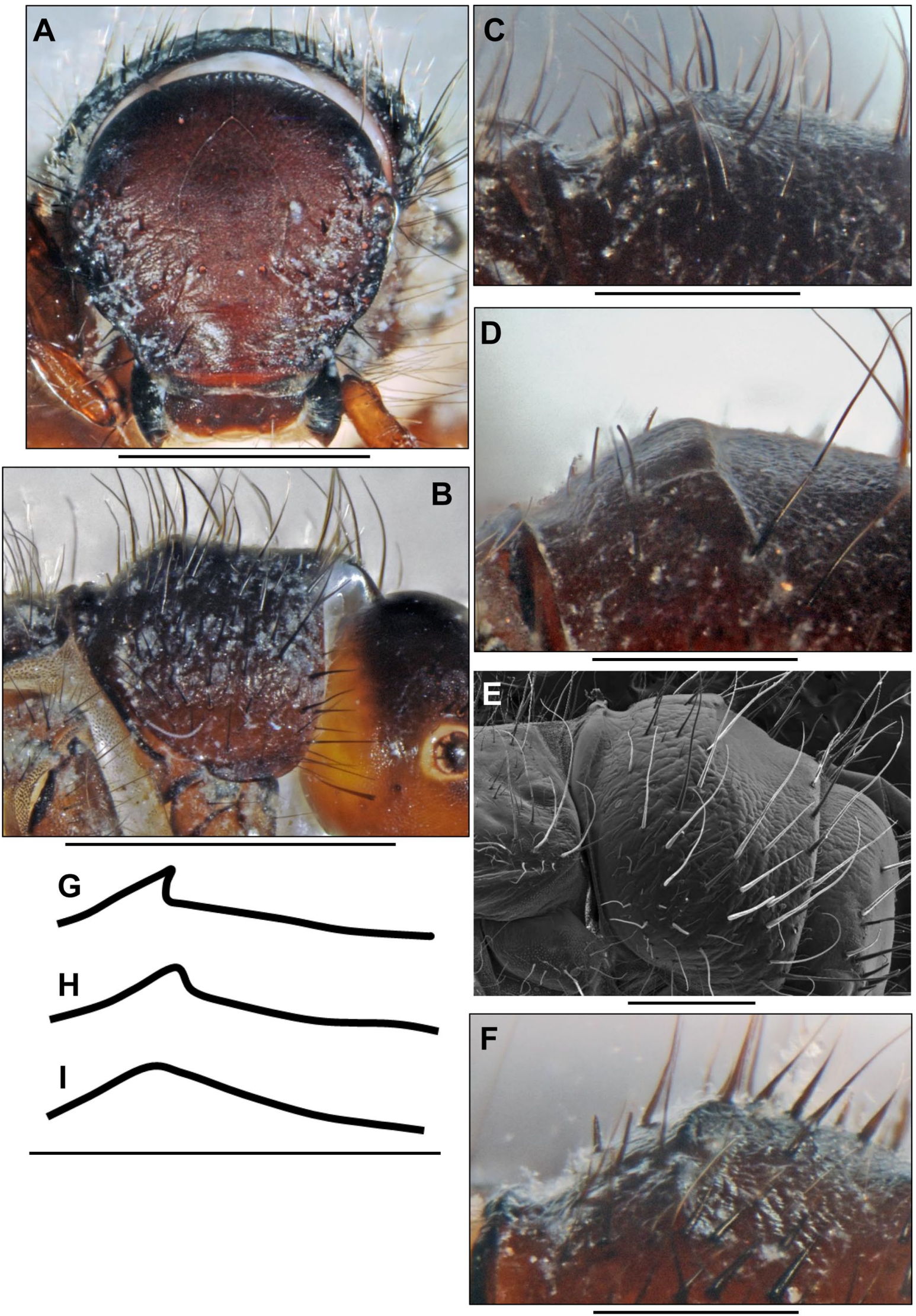

Fig. 7. A-C, Drusus tenellus (5th instar larva): A - head and pronotum, frontal view; B - head and pronotum, right lateral view; C - detail of central notch, right dorsolateral view. D, E - Drusus schmidi (5th instar larva): D - detail of central notch, right dorsolateral view; E - head, pro- and mesonotum, right lateral view. F - Ecclisopteryx madida (5th instar larva), detail of central notch, right dorsolateral view. G-I - schematic cross sections (right lateral view) of central pronotal ridges (5th instar larvae): G - Ecclisopteryx madida; $\mathrm{H}$ - Drusus schmidi; I - Drusus tenellus. Scale bars: A, F-I = $1 \mathrm{~mm}$; B-E $=0.5 \mathrm{~mm}$. 

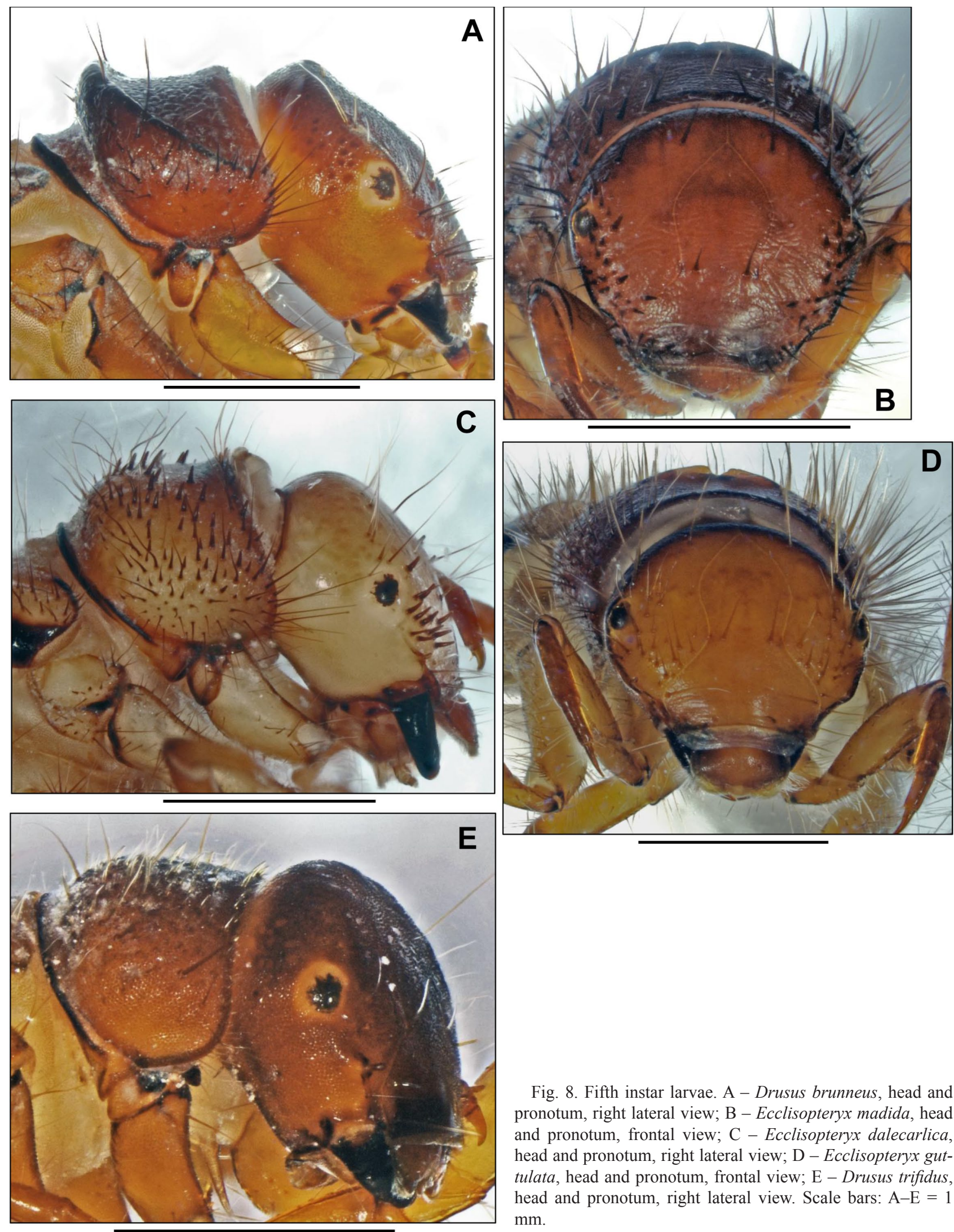

Fig. 8. Fifth instar larvae. A - Drusus brunneus, head and pronotum, right lateral view; B - Ecclisopteryx madida, head and pronotum, frontal view; C - Ecclisopteryx dalecarlica, head and pronotum, right lateral view; D - Ecclisopteryx guttulata, head and pronotum, frontal view; E - Drusus trifidus, head and pronotum, right lateral view. Scale bars: $A-E=1$ $\mathrm{mm}$.

Habitat. Drusus balcanicus is confined to oxygen-rich headwaters of streams and to springs. Data logger records over a full year revealed arithmetric means of water tem- peratures for typical habitats of D. balcanicus (e.g., springs below the Troyan pass, Bulgaria) of $6.65^{\circ} \mathrm{C}$ (range $1.08-$ $\left.15.44^{\circ} \mathrm{C}\right)$. This species grazes epilithic algae. 
TABLE 4. Synopsis of the characters separating the currently known Drusinae larvae (5th instars) with spoon-shaped mandibles and no spinule areas, additional bristles or spines on the head capsule (i.e., only the standard set of 18 pairs of primary setae is present).

\begin{tabular}{|c|c|c|c|c|c|c|}
\hline Species & $\begin{array}{l}\text { Dorsal } \\
\text { gills } \\
\text { present? }\end{array}$ & $\begin{array}{l}\text { Basal sclerites of setae on first ab- } \\
\text { dominal sternum fused to sclerotized } \\
\text { plates or in multilobed patterns? }\end{array}$ & $\begin{array}{l}\text { Anterior-row setae } \\
\text { present near dorsal } \\
\text { pronotal midline? }\end{array}$ & $\begin{array}{l}\text { Dorsal edge setae on } \\
\text { entire length of mid- } \\
\text { and hind tibia? }\end{array}$ & $\begin{array}{l}\text { Pronotum } \\
\text { evenly } \\
\text { rounded? }\end{array}$ & References \\
\hline Drusus carpathicus & no & no & yes & no & yes & Szczesny (1978) \\
\hline $\begin{array}{l}\text { Drusus improvisus } \\
\text { Drusus rectus } \\
\text { Drusus spelaeus } \\
\text { Metanoea flavipennis } \\
\text { Metanoea rhaetica }\end{array}$ & yes & yes & yes & no & yes & $\begin{array}{c}\text { Table } 5 \\
\text { (present paper) }\end{array}$ \\
\hline $\begin{array}{l}\text { Drusus balcanicus } \\
\text { Drusus franzressli } \\
\text { Drusus nigrescens } \\
\text { Ecclisopteryx malickyi }\end{array}$ & yes & yes & yes & no & no & $\begin{array}{c}\text { Table } 5 \\
\text { (present paper) }\end{array}$ \\
\hline Drusus camerinus & yes & yes & no & no & yes & Waringer et al., 2008a \\
\hline $\begin{array}{l}\text { Drusus melanchaetes } \\
\text { Drusus adustus }\end{array}$ & yes & no & yes & yes & yes & $\begin{array}{c}\text { Graf (1993) } \\
\text { Waringer et al. (2008b) }\end{array}$ \\
\hline $\begin{array}{l}\text { Anomalopterygella } \\
\quad \text { chauviniana } \\
\text { Drusus bolivari } \\
\text { Drusus monticola } \\
\text { Drusus ramae }\end{array}$ & yes & no & yes & no & no & $\begin{array}{c}\text { Urbanič et al. (2003) } \\
\text { Vieria-Lanero et al. (2005) } \\
\text { Kučinić et al. (2010) } \\
\text { Waringer et al. (2010) } \\
\text { Waringer \& Graf (2011) }\end{array}$ \\
\hline $\begin{array}{l}\text { Drusus annulatus } \\
\text { Drusus biguttatus } \\
\text { Drusus ingridae } \\
\text { Drusus rectus } \\
\text { Drusus vinconi } \\
\text { Ecclisopteryx asterix } \\
\text { Hadimina torosensis } \\
\text { Leptodrusus budtzi }\end{array}$ & yes & no & yes & no & yes & $\begin{array}{c}\text { Moretti \& Pirisinu (1981) } \\
\text { Sipahiler (2002) } \\
\text { Urbanič et al. (2003) } \\
\text { Waringer et al. (2013b) }\end{array}$ \\
\hline $\begin{array}{l}\text { Drusus aprutiensis } \\
\text { Drusus camerinus } \\
\text { Drusus croaticus } \\
\text { Drusus mixtus } \\
\text { Drusus trifidus }\end{array}$ & yes & no & no & no & yes & $\begin{array}{l}\text { Kučinić et al. (2008) } \\
\text { Waringer et al. (2008a, } \\
\text { 2010, 2011) }\end{array}$ \\
\hline
\end{tabular}

\section{Diagnosis of species of Drusus of the grazer clade lacking areas of spinules or additional spines on head capsule}

Mandibles are spoon-shaped (Fig. 1E). The larva of Drusus balcanicus lacks spinule areas and additional bristles and spines on its head capsule (Fig. 4C; Table 4). Dorsal gills present; basal sclerites of setae on the first abdominal sternum fused to sclerotized plates or form multilobed patterns (Fig. 5B); anterior row of setae present near the dorsal pronotal midline (Fig. 4C); mid and hind legs with dorsal edge setae restricted to distal third of tibiae. It shares these features with Drusus franzressli, D. improvisus, D. nigrescens Meyer-Dür, 1875, D. rectus, D. spelaeus, Ecclisopteryx malickyi Moretti, 1991, Metanoea flavipennis and $M$. rhaetica. Due to the presence of a low central ridge on the pronotum, the larva of D. balcanicus is similar to that of Drusus franzressli (Table 5), but the latter also has a distinct lateral ridge (Fig. 5F, arrows) which is absent in $D$. balcanicus (Fig. 4F). In addition, the basal sclerites of the central setae on the first abdominal sternum are fused into a large, uniform central plate (Fig. 5G) in D. franzressli and form a multilobed sclerotized pattern in D. balcanicus (Figs 5B-D).

\section{Drusus botosaneanui Kumanski, 1968}

Material examined. 2 ex. of fifth instar, Gornje Lukovo polje

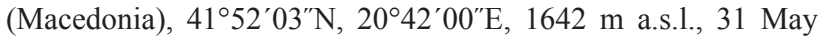
2012, leg. Kučinić, Krpač.

General morphology. Larva eruciform, head and sclerotized parts dark brown, nonsclerotised parts whitish. Body length $10.3-10.5 \mathrm{~mm}$, head width $1.26-1.30 \mathrm{~mm}$.

Head. Head capsule roundish, dark brown with lighter orange areas around foramen occipitale and a smooth surface sculptured by shallow wrinkles (Figs 5H, I). Each parietale with 20-25 long bristles and short, strongly tapering spines plus a standard set of 12 primary setae, mostly anterior and dorsal to the eye. Also on frontoclypeus there are 12-18 long bristles and short, strongly tapering spines, plus standard set of 6 pairs of primary setae, mostly on anterolateral corners (Figs 5H, I).

Ventral apotome orange, broadly bell-shaped; postgenal suture approximately $60-66 \%$ of apotome length.

Thorax. Pronotum dark brown to blackish brown. Pronotal surface relatively smooth, sculptured by shallow wrinkles (Figs 6C, D). Dorsal profile in lateral view with low ridge not elongated laterally. Ridge gently ascending from posterior pronotal border with a distinct step leading down to anterior, lower $2 / 3$ of pronotum (Figs 6B, D). In anterior view with deep central notch flanked by two an- 
TABLE 5. Synopsis of characters separating the currently known Drusinae larvae (5th instars), which share the following group morphomatrix: Spoon-shaped mandibles; lack of additional head bristles, spines or spinule areas; setae of anterior row present near dorsal pronotal midline; dorsal gills present; setae on dorsal edge restricted to distal third of mid- and hind tibiae; basal sclerites of setae on first abdominal sternum fusing into sclerotized plates or multilobed patterns.

\begin{tabular}{|c|c|c|c|c|c|c|c|}
\hline Species & $\begin{array}{l}\text { Dorsal outline } \\
\text { of pronotum / median } \\
\text { incision present? }\end{array}$ & $\begin{array}{c}\text { Pronotal } \\
\text { sculpturing }\end{array}$ & $\begin{array}{l}\text { Sclerotization on } \\
\text { 1st abdominal } \\
\text { sternum }\end{array}$ & $\begin{array}{l}\text { Posterolateral gills } \\
\text { present on } 2 \text { nd and 3rd } \\
\text { abdominal segment? }\end{array}$ & $\begin{array}{l}\text { Start of } \\
\text { lateral } \\
\text { fringe }\end{array}$ & Distribution & References \\
\hline $\begin{array}{l}\text { Drusus } \\
\text { nigrescens }\end{array}$ & $\begin{array}{l}\text { high ridge / } \\
\text { yes }\end{array}$ & $\begin{array}{l}\text { coarsely granu- } \\
\text { lated, ribbed }\end{array}$ & $\begin{array}{l}\text { multilobed scle- } \\
\text { rotized pattern }\end{array}$ & yes & $\begin{array}{c}\text { last third } \\
\text { III }\end{array}$ & $\begin{array}{l}\text { western } \\
\text { alpine }\end{array}$ & $\begin{array}{l}\text { Waringer et } \\
\text { al. (2007) }\end{array}$ \\
\hline $\begin{array}{l}\text { Ecclisopteryx } \\
\text { malickyi }\end{array}$ & $\begin{array}{l}\text { high ridge / } \\
\text { no }\end{array}$ & $\begin{array}{c}\text { coarsely } \\
\text { granulated }\end{array}$ & $\begin{array}{l}\text { multilobed scle- } \\
\text { rotized pattern }\end{array}$ & yes & $\begin{array}{c}\text { last third } \\
\text { III }\end{array}$ & $\begin{array}{l}\text { southern } \\
\text { alpine }\end{array}$ & $\begin{array}{c}\text { Graf et al. } \\
(2011)\end{array}$ \\
\hline $\begin{array}{l}\text { Drusus } \\
\text { franzressli }\end{array}$ & $\begin{array}{c}\text { low central ridge / } \\
\text { no }\end{array}$ & $\begin{array}{l}\text { coarsely } \\
\text { granulated }\end{array}$ & central plate & no & $\begin{array}{l}\text { first third } \\
\text { II }\end{array}$ & $\begin{array}{l}\text { Hellenic } \\
\text { Western } \\
\text { Balkans }\end{array}$ & $\begin{array}{l}\text { Waringer et } \\
\text { al. (2013a) }\end{array}$ \\
\hline $\begin{array}{l}\text { Drusus } \\
\text { balcanicus }\end{array}$ & $\begin{array}{c}\text { low central ridge / } \\
\text { no }\end{array}$ & $\begin{array}{l}\text { coarsely granu- } \\
\text { lated, ribbed }\end{array}$ & $\begin{array}{l}\text { multilobed scle- } \\
\text { rotized pattern }\end{array}$ & no & $\begin{array}{l}\text { first third } \\
\text { II }\end{array}$ & $\begin{array}{l}\text { Eastern } \\
\text { Balkans }\end{array}$ & $\begin{array}{l}\text { present } \\
\text { paper }\end{array}$ \\
\hline $\begin{array}{l}\text { Drusus } \\
\text { improvisus }\end{array}$ & $\begin{array}{l}\text { evenly rounded, } \\
\text { high profile / no }\end{array}$ & $\begin{array}{l}\text { coarsely granu- } \\
\text { lated, ribbed }\end{array}$ & $\begin{array}{l}\text { multi-lobed scle- } \\
\text { rotized pattern }\end{array}$ & yes & $\begin{array}{l}\text { last third } \\
\text { II }\end{array}$ & Apennines & $\begin{array}{l}\text { Waringer et } \\
\text { al. (2008a) }\end{array}$ \\
\hline $\begin{array}{l}\text { Drusus } \\
\text { rectus }\end{array}$ & $\begin{array}{l}\text { evenly rounded, } \\
\text { low profile/no }\end{array}$ & $\begin{array}{l}\text { coarsely granu- } \\
\text { lated, ribbed }\end{array}$ & $\begin{array}{l}\text { multilobed scle- } \\
\text { rotized pattern }\end{array}$ & yes & $\begin{array}{c}\text { last third } \\
\text { III }\end{array}$ & $\begin{array}{c}\text { Pyrenees, } \\
\text { Massif central }\end{array}$ & $\begin{array}{c}\text { unpubl. } \\
\text { data }\end{array}$ \\
\hline $\begin{array}{l}\text { Drusus } \\
\text { spelaeus }\end{array}$ & $\begin{array}{l}\text { evenly rounded, } \\
\text { low profile / no }\end{array}$ & $\begin{array}{l}\text { coarsely granu- } \\
\text { lated, ribbed }\end{array}$ & $\begin{array}{l}\text { central plate or } \\
\text { multi-lobed scle- } \\
\text { rotized pattern }\end{array}$ & yes & $\begin{array}{l}\text { last third } \\
\text { II }\end{array}$ & $\begin{array}{l}\text { western } \\
\text { alpine }\end{array}$ & $\begin{array}{l}\text { Waringer et } \\
\text { al. (2013a) }\end{array}$ \\
\hline $\begin{array}{l}\text { Metanoea } \\
\text { flavipennis }\end{array}$ & $\begin{array}{l}\text { evenly rounded, } \\
\text { low profile / no }\end{array}$ & $\begin{array}{c}\text { finely } \\
\text { granulated }\end{array}$ & central plate & yes & $\begin{array}{l}\text { last third } \\
\text { II }\end{array}$ & $\begin{array}{l}\text { western } \\
\text { alpine }\end{array}$ & $\begin{array}{l}\text { Waringer et } \\
\text { al. (2000) }\end{array}$ \\
\hline $\begin{array}{l}\text { Metanoea } \\
\text { rhaetica }\end{array}$ & $\begin{array}{l}\text { evenly rounded, } \\
\text { low profile / no }\end{array}$ & $\begin{array}{c}\text { finely } \\
\text { granulated }\end{array}$ & central plate & no & $\begin{array}{l}\text { last third } \\
\text { II }\end{array}$ & $\begin{array}{l}\text { eastern } \\
\text { alpine }\end{array}$ & $\begin{array}{l}\text { Waringer } \\
(1985)\end{array}$ \\
\hline
\end{tabular}

teriorly directed hooks (Figs 6B-D). In total, 60-75 long dark bristles and short, strongly tapering spines are distributed over each pronotal half. Prosternite light brown, with medium brown anterolateral corners, trapezoidal in shape and tapering posteriorly.

Mesonotal sclerites dark brown to blackish brown with lateral and posterior margins darkly sclerotized. There are 15-25 setae in anterior setal group sa1, 17-35 in posterior group $s a 2$ and 18-25 in lateral group sa3 (Fig. 6D).

Dark brown anterior $s a 1$ metanotal sclerites ovoid, with approximately 25-30 setae per sclerite (Fig. 6D). Setal counts on medium brown posteromedian $s a 2$ sclerites are 15-20 and on lateral $s a 3$ sclerites 17-25 setae per sclerite, respectively; the latter sclerites medium brown with black brown markings (Fig. 6E). Legs medium to dark brown. All other details as in D. serbicus.

Abdomen. Posterior sclerite present on lateral protuberances. On 1st abdominal sternum, ventral setal areas $s a 1$, $s a 2$ and $s a 3$ fused, creating continuous field of 70-100 setae; basal sclerites of setae in the central area of the first abdominal sternum mostly small and inconspicuous except for four larger basal sclerites near midline and immediately ventral to the lateral protuberances (Fig. 6F). Eighth abdominal dorsum with 2 to 4 long and 4 short posterodorsal setae (pds). Only 1 posterolateral seta is present on each half of 9th abdominal dorsum. Light to medium brown sclerite on 9th abdominal tergum semicircular, with 10 long and several shorter setae along its posterior border, 2 of the long setae in the position of central intermediate $c$ setae.
Dorsal gills present at most on 2nd (presegmental position) to 7th segment (postsegmental position). Ventral gills on 2nd (presegmental) to 7th segment (postsegmental). Dorsolateral gills on 2nd (presegmental) to 4th segment (presegmental) and ventrolateral gills on 2nd (postsegmental) to 4th segment (postsegmental). Lateral fringe extending from beginning of 3rd to first third of 8th abdominal segment.

Case. Larval case 10.2-10.4 mm long $(\mathrm{n}=2)$, curved, conical. Width at anterior opening $3.1-3.3 \mathrm{~mm}$ and at posterior opening 1.9-2.2 $\mathrm{mm}$. Case consists of mineral particles (sand grains of mixed size; Fig. 6G).

Habitat. Drusus botosaneanui inhabits springs and the upper regions of the headwaters of streams as well as midstream regions of rivers at 655 to $1450 \mathrm{~m}$ above sea level (Ibrahimi et al., 2012). Mean annual water temperatures of the sites inhabited by $D$. botosaneanui (e.g., tributary of Beli Iskar, Bulgaria) were $5.66^{\circ} \mathrm{C}$ (annual range 0.08 $14.38^{\circ} \mathrm{C}$ ). This species grazes on biofilms and epilithic algae.

\section{Drusus tenellus (Klapálek, 1898)}

Material examined. 3 ex. of fifth instar, Mavrovo, Lukovo Pole (Macedonia), $41^{\circ} 42^{\prime} 03^{\prime \prime} \mathrm{N}, 20^{\circ} 39^{\prime} 52^{\prime \prime} \mathrm{E}, 1665 \mathrm{~m}$ a.s.l., 3 July 2010, leg. Previšić; 2 ex. of fifth instar, Murinska Rijeka (Montenegro), $42^{\circ} 39^{\prime} 18^{\prime \prime} \mathrm{N}, 19^{\circ} 52^{\prime} 48^{\prime \prime} \mathrm{E}, 878 \mathrm{~m}$ a.s.l., 5 July 2012 , leg. Previšić.

General morphology. Larva eruciform, head and sclerotized parts dark brown, nonsclerotised parts whitish. Body length of final instar larva $10.7-12.9 \mathrm{~mm}$, head width $1.24-1.34 \mathrm{~mm}$. 
TABLE 6. Synopsis of characters separating the currently known Drusinae larvae (5th instars) with spoon-shaped mandibles and with additional bristles and spines on the head capsule (in addition to the standard set of 18 pairs of primary setae).

\begin{tabular}{|c|c|c|c|c|c|}
\hline Species & $\begin{array}{l}\text { Pronotum with ridge } \\
\text { extending laterally to the } \\
\text { anterior pronotal margin? }\end{array}$ & $\begin{array}{l}\text { Dorsal outline of pro- } \\
\text { notum / deep median } \\
\text { incision present? }\end{array}$ & $\begin{array}{l}\text { Number of setae, } \\
\text { spines and bristles on } \\
\text { the frontoclypeus }\end{array}$ & $\begin{array}{l}\text { Colour of pronotal } \\
\text { setae, spines and } \\
\text { bristles }\end{array}$ & References \\
\hline Drusus brunneus & yes & high ridge / no & $>20$ & black brown & Szczesny (1978) \\
\hline Drusus botosaneanui & no & low central ridge / yes & $>20$ & black & present paper \\
\hline Ecclisopteryx guttulata & no & low central ridge / yes & $12-16$ & black brown & $\begin{array}{c}\text { Szczesny (1978); } \\
\text { Pitsch (1993); } \\
\text { Waringer \& Graf } \\
\text { (2011) }\end{array}$ \\
\hline Ecclisopteryx madida ${ }^{1}$ & no & low central ridge / no & $>20$ & black brown & $\begin{array}{l}\text { Szczesny (1978); } \\
\text { Pitsch (1993); } \\
\text { Waringer \& Graf } \\
(2011)\end{array}$ \\
\hline Drusus schmidi ${ }^{1}$ & no & low central ridge / no & $>20$ & black & $\begin{array}{l}\text { Kučinić et al. (un- } \\
\text { publ. data) }\end{array}$ \\
\hline Drusus tenellus ${ }^{1}$ & no & low central ridge / no & $>20$ & black & present paper \\
\hline $\begin{array}{l}\text { Ecclisopteryx keroveci }^{2} \\
\text { Ecclisopteryx ivkae }^{2}\end{array}$ & no & low central ridge / no & 12 & black brown & Previšić et al. (2014) \\
\hline Drusus trifidus & no & evenly rounded / no & 12 & pale yellow & Szczesny (1978) \\
\hline $\begin{array}{l}\text { Ecclisopteryx } \\
\text { dalecarlica }\end{array}$ & no & evenly rounded / no & $12-16$ & black brown & $\begin{array}{c}\text { Szczesny (1978); } \\
\text { Pitsch (1993); } \\
\text { Waringer \& Graf } \\
(2011)\end{array}$ \\
\hline
\end{tabular}

${ }^{1}$ In E. madida, the pronotal ridge is rather sharp and almost concave anteriorly (Figs 7F, G; 8B), in $D$. schmidi there is a distinct step (Figs 7D, E, H), and in D. tenellus the anterior section of the ridge gently slopes down to the anterior part of the pronotum (Figs 7B, C, I). ${ }^{2}$ In E. keroveci, the number of additional spines on each parietale is 12-20, in E. ivkae 1-7.

Head. Head capsule roundish, dark brown with lighter orange areas around foramen occipitale and with smooth surface sculptured by shallow wrinkles (Figs 7A, B). Setation as in D. botosaneanui. Ventral apotome orange, narrow and parallel-sided; postgenal suture approximately $60-66 \%$ of apotome length.

Thorax. Pronotum dark brown to blackish brown. Pronotal surface coarsely granulated with adjacent series of granuli creating ribbed structures (Fig. 7B). Dorsal profile in lateral view with low ridge not elongated laterally. Joint between the posterior and anterior sides of ridge smooth and lacking distinct step; anterior side gently sloping down to anterior part of pronotum (Figs 7B, C, 7I). Central notch very shallow, flanking anteriorly directed hooks absent (Figs 7A, C). In total, 60-75 long dark bristles and short, strongly tapering spines scattered over each pronotal half. Prosternite light brown, with medium brown anterolateral corners, trapezoidal in shape and tapering posteriorly.

Mesonotal sclerites dark brown to blackish brown with lateral and posterior margins darkly sclerotized. Number of setae in anterior setal group $s a 1$ 15-25, in posterior group $s a 2$ 17-35 and in lateral group sa3 18-25.

Dark brown anterior $s a 1$ metanotal sclerites ovoid, with 15-20 setae. Setal counts for medium brown posteromedian sa2 sclerites are 15-20 setae per sclerite and lateral sa3 sclerites 17-25, respectively; the latter sclerites medium brown with black brown markings. Legs medium to dark brown. All other details as in D. serbicus.
Abdomen. Posterior sclerite absent. First abdominal sternum as in D. botosaneanui. On 8th abdominal dorsum, there are 2 to 4 long and 4 short posterodorsal setae (pds). Only 1 posterolateral seta on each half of 9th abdominal dorsum. Sclerite on 9th abdominal tergum as in D. botosaneanui.

Dorsal gills present at most on 2nd (presegmental position) to 7 th segment (postsegmental position). Ventral gills on 2nd (presegmental) to 7th segment (postsegmental). Dorsolateral gills on 2nd (presegmental) to 4th (presegmental) and ventrolateral gills on 2nd (postsegmental) to 4th segment (postsegmental). Lateral fringe extending from beginning of 3rd to first third of 8th abdominal segment.

Case. Larval case 11.0-11.5 mm long $(\mathrm{n}=3)$, curved, conical. Width at anterior opening 2.7-3.0 mm and at posterior opening 1.9-2.0 mm. Case consists of mineral particles (sand grains of mixed size).

Habitat. D. tenellus prefers the epi- and metarhithral zone of oxygen-rich streams with high to moderate currents at altitudes $>1450 \mathrm{~m}$ a.s.l. Mean annual water temperature for sites inhabited by D. tenellus (e.g., Strežimirska reka, Mavrovo, Macedonia) were $6.87^{\circ} \mathrm{C}$ (annual range $5.11-8.54^{\circ} \mathrm{C}$ ). This species is a grazer of biofilms and epilithic algae.

\section{Diagnosis of species of Drusus of the grazer clade with} additional spines on head capsule

Mandibles are spoon-shaped (Fig. 1E). Drusus botosaneanui and D. tenellus belong to the group of Drusinae 
species, which, in addition to their standard set of 18 pairs of primary setae, have short, thick spines or long, tapering bristles on each parietale (and frontoclypeus in some species): Drusus brunneus, D. schmidi, D. trifidus, Ecclisopteryx dalecarlica, E. guttulata, E. ivkae Previšić, Graf \& Vitecek, 2014, E. keroveci Previšić, Graf \& Vitecek, 2014 and E. madida (Table 6). Because the number of frontoclypeal setae is $>20$ (Figs 5I, 7A) and the dorsal ridge (Figs $6 \mathrm{~B}, 7 \mathrm{~B})$ does not extend to the anterolateral corners of the pronotum as in D. brunneus (Fig. 8A), D. botosaneanui and D. tenellus key out with Ecclisopteryx madida and Drusus schmidi. D. botosaneanui can be easily separated from the other three species by the deep central notch in its pronotal ridge, flanked by two anteriorly directed hooks (Figs 6B-D). In Drusus schmidi, D. tenellus and Ecclisopteryx madida the central notch is very shallow (Figs 7A, C-F, $8 \mathrm{~B})$ and without hooks. These species can be separated by the profile of the central pronotal ridge: in E. madida, the ridge is rather sharp and almost concave anteriorly (Figs $7 \mathrm{~F}, \mathrm{G}, 8 \mathrm{~B}$ ), in $D$. schmidi there is a distinct step (Figs 7D, $\mathrm{E}, \mathrm{H})$, and in D. tenellus the anterior side of the ridge gently slopes toward the anterior part of the pronotum (Figs $7 \mathrm{~B}, \mathrm{C}, \mathrm{I})$.

\section{DISCUSSION}

Previous studies that associated adults and larvae in caddisflies have used COI (e.g., Waringer et al., 2008b; Graf et al., 2009), COI \& WG (Waringer et al., 2013a), COI \& 28S rDNAs (Zhou et al., 2007), or COI, WG \& LSU sequences (Previšić et al., 2014). The additional use of WG, LSU and CAD did not bring additional information to our $1200 \mathrm{bp}$ long COI sequences. However, the use of unlinked nuclear markers provides independent support for the sorting of mitochondrial lineages, which could also result from historical isolation of presently admixed populations (e.g., Elbrecht et al., 2014). It is thus advisable to use both nuclear and mitochondrial markers for life stage associations. The nuclear genes we used, WG and CAD, proved sufficiently variable to discern species in this study. The level of variation is similar in WG and even higher in CAD compared with COI. Of the two genes we used, CAD performed somewhat better in our study, but both seem suitable for associating life stages of caddisflies.

All four species described in the present paper belong to the largest group of epilithic grazers, which lack terminal teeth on their mandibles (Figs 1D, E, 4D). Based on the presence or absence of bristles and setae in addition to the standard set of 18 pairs of primary setae on the larval head capsule, the grazer clade is separated into three subgroups:

Subgroup 1 with an area of spinules posterior to each eye (Figs 1E, F; white ovals). Such spinule areas occur in members of the Drusus bosnicus Group. MarinkovićGospodnetić (1971a) assigned D. bosnicus, D. klapaleki, D. plicatus Radovanović, 1942, D. radovanovici and D. ramae Marinković-Gospodnetić, 1971 b to the $D$. bosnicus Group based on similarity of main structures of the male genitalia. Later, D. krusniki Malicky, 1981, D. medianus, $D$. septentrionis and $D$. vespertinus were added to this group (see discussion in Kučinić et al., 2011a). Of these species, the spinules are absent in D. ramae. They are present in the hitherto unknown larva of $D$. serbicus.

In subgroup 2 of the grazer clade, additional spines and bristles are present on the parietalia and/or the frontoclypeus; this is the case in Ecclisopteryx dalecarlica, E. guttulata, E. ivkae, E. keroveci, E. madida, Drusus brunneus, D. schmidi, D. trifidus, and the hitherto unknown larvae of D. botosaneanui and D. tenellus (Figs 5H, I, 6A, B, 7A). In this group, $D$. trifidus has only $0-2$ additional spines per parietale.

Finally, D. balcanicus belongs to the largest subgroup of the grazer clade, in which only the standard set of primary setae is present on the head capsule (Figs 4C, D).

The spines that define the subgroup 2 (e.g., Figs $5 \mathrm{H}$, I, 7A) have a length of $0.4 \mathrm{~mm}$ or more in Ecclisopteryx guttulata and are one magnitude longer than the spinules in Drusus serbicus and associated species measuring up to $0.03 \mathrm{~mm}$. These morphological traits are in line with distinct differences in downstream distribution patterns: species with additional spines on their head capsule (morphological features summarized in Table 6) are most abundant in the epi- and metarhithral section, whereas Drusinae species without spines or with spinules are only found in spring or spring brook sections (eucrenal-hypocrenal). Statzner \& Higler (1985) have shown that the eucrenal and hypocrenal sections of streams (source and springbrooks) are frequently characterized by relatively low hydraulic stress. The hypocrenal-epirhithral transition zone is followed by a section with high hydraulic stress, which, after the next zone of transition at the break-point of the slope, is then followed by a zone of lower hydraulic stress (Statzner \& Higler, 1985). As Drusinae larvae face into the current (own observation), the presence of spines on the head capsule of this species group summarized in Table 6 may be associated with their presence in such hydrologically high-stress sections within the stream continuum. Videler (1995) has shown that small irregularities in the scales of fish can reduce shear stress in the boundary by a maximum of $10 \%$ compared with the shear stress of a smooth surface, a mechanism based on the impedance of cross flow under well-defined conditions. The function of roughness probably reduces total drag by generating premature turbulence and by boundary layer thinning, despite an increased friction over the surface (Videler, 1995).

The adults and larvae of Drusus serbicus, D. botosaneanui and D. balcanicus were sampled in the months of May and June in 2012 and 2013, and of D. tenellus in July 2010. This is in accordance with the reported spring flight period of D. serbicus as the type and paratype specimens were collected on 30 May 1970 (Marinković-Gospodnetić, 1971a). Drusus balcanicus is also a spring and early summer species with a rather short flight period, whereas it is longer in D. botosaneanui, which is on the wing from spring to autumn (Graf et al., 2008). A prolonged flight period has also been recorded for D. tenellus, for which adults are still being collected in the first week of October (Oláh \& Kovács, 2013). 
With respect to distribution, D. balcanicus is a species (micro-) endemic to the eastern Balkan Peninsula where it is restricted to the Stara Planina and Vitosha, whereas $D$. serbicus is (micro-) endemic to the Dinaric Western Balkans and restricted to the Dinaric Alps. Drusus tenellus has a wider range, with records from the Carpathians and the Dinaric Eastern Balkans. The distribution of D. botosaneanui is even wider, covering the Dinaric Western Balkans, the Hellenic and Eastern Balkans as well as Asia Minor.

ACKNOWLEDGEMENTS. We are grateful to the Mavrovo NP Authorities (Macedonia) for granting us permission to sample in the NP. This paper includes some of the results of the project "The Drusinae (Insecta: Trichoptera) in a world of global change" (project number P23687-B17, PI: J. Waringer) funded by the Austrian Science Fund (FWF). The work was also partly supported by a grant from the Ministry of National Education, Romania (CNCSIS-UEFISCDI, project number PN-II-ID-PCE-2012-4-0595), and the University of Zagreb, Croatia (Project No. 202310).

\section{REFERENCES}

AQEM CONSORTIUm 2002: Manual for the Application of the AQEM System. A Comprehensive Method to Assess European Streams Using Benthic Macroinvertebrates, Developed for the Purpose of the Water Framework Directive. Version 1_0. Available from http://www.aqem.de (accessed 25 June 2014).

Barbour M.T. \& Yoder C.O. 2000: The multimetric approach to bioassessment, as used in the United States. In Wright J.F., Sutcliffe D.W. \& Furse,M.T. (eds): Assessing the Biological Quality of Fresh Waters: RIVPACS and Other Techniques. Freshwater Biological Association, Ambleside, UK, pp. 281-292.

Barbour M.T., Gerritsen J., Snyder B.D. \& Stribling J.B. 1999: Rapid Bioassessment Protocols for use in Wadeable Streams and Rivers: Periphyton, Benthic Macroinvertebrates and Fish 2nd ed. EPA 841-B-99-002. U.S. Environmental Protection Agency, Washington, D.C., xii +326 pp.

Drummond A.J. \& Rambaut A. 2007: BEAST: Bayesian evolutionary analysis by sampling trees. - BMC Evol. Biol. 7: 214 .

Elbrecht V., Feld C.K., Gies M., Hering D., Sondermann M., TollRian R. \& LeEse F. 2014: Genetic diversity and dispersal potential of the stonefly Dinocras cephalotes in a central European low mountain range. - Freshw. Sci. 33: 181-192.

Folmer O., Black M., Hoen W., Lutz R. \& Vrijenhoek R. 1994: DNA primers for amplification of mitochondrial cytochrome $\mathrm{c}$ oxidase subunit I from diverse metazoan invertebrates. - Mol. Mar. Biol. Biotechnol. 3: 294-299.

GraF W. 1993: Beschreibung der Larven von Rhyacophila producta und Rhyacophila stigmatica und einer Larve aus der Unterfamilie Drusinae (Trichoptera: Rhyacophilidae, Limnephilidae). - Braueria 20: 17-18.

Graf W., Grasser U. \& Waringer J. 2002: Trichoptera. Teile IIIA, IIIB, IIIC, IIID. In Moog O. (ed.): Fauna Aquatica Austriaca. 2nd ed. Bundesministerium für Land- und Forstwirtschaft, Wien, $41 \mathrm{pp}$.

Graf W., Murphy J., Dahl J., Zamora-Muñoz C. \& López-RodRíGuez M.J. 2008: Vol. 1 - Trichoptera. In Schmidt-Kloiber A. \& Hering D. (eds): Distribution and Ecological Preferences of European Freshwater Organisms. Pensoft Publishers, Sofia, Moscow, 388 pp.

Graf W., Waringer J. \& Pauls S.U. 2009: A new feeding group within larval Drusinae (Trichoptera: Limnephilidae): the Drusus alpinus Group sensu Schmid, 1956, including larval descriptions of Drusus franzi Schmid, 1956, and Drusus alpinus (Meyer-Dür, 1875). - Zootaxa 2031: 53-62.

Graf W., Kučinić M., Previšić A., Pauls S.U. \& Waringer J. 2011: The larva of Ecclisopteryx malickyi Moretti, 1991
(Trichoptera: Limnephilidae; Drusinae) with comments on the genus. - Zoosymposia 5: 136-142.

Hering D., Johnson R.K., Kramm S., Schmutz S., Szoszkiewicz K. \& Verdonschot P.F.M. 2006: Assessment of European streams with diatoms, macrophytes, macro-invertebrates and fish: A comparative metric-based analysis of organism response to stress. - Freshw. Biol. 51: 1757-1785.

IBRAhIMI H., KuČInIĆ M., GASHI A. \& GRAPCi-Kotori L. 2012: The caddisfly fauna (Insecta, Trichoptera) of the rivers of the Black Sea basin in Kosovo with distributional data for some rare species. - ZooKeys 182: 71-85.

Johanson K.A. \& MaLm T. 2010: Testing the monophyly of Calocidae (Insecta: Trichoptera) based on multiple molecular data. - Mol. Phylogenet. Evol. 54: 535-541.

Kučinić M., Previšsić A., Gottstein S., Hrašovec B., StanićKoštroman S., Pernek M. \& Delić A. 2008: Description of the larva of Drusus radovanovici septentrionis MarinkovićGospodnetić, 1970 and Drusus croaticus MarinkovićGospodnetić, 1971 (Trichoptera: Limnephilidae) from Bosnia and Herzegovina and Croatia. - Zootaxa 1983: 1-17.

Kučinić M., Previšić A., Stanić-Koštroman S., Franević M., Šerić Jelaska L., Delić A. \& Posilović H. 2010: Description of the larvae of Drusus ramae Marinković-Gospodnetić and Drusus medianus Marinković-Gospodnetić (Trichoptera: Limnephilidae) with some genetic, distributional, ecological, faunal and conservation notes. - Zootaxa 2484: 1-24.

Kučinić M., Previšić A., Graf W., Šeric Jelaska L., StanićKoŠtroman S. \& WARINGER J. 2011a: Larval description, genetic and ecological features of Drusus radovanovici radovanovici Marinković-Gospodnetić, 1971 (Trichoptera: Limnephilidae) with some phylogenetic and taxonomic data on the bosnicus group in the Balkan Peninsula. - Dt. Entomol. Z. 58: 136-153. Kučinić M., Previšić A., Stanić-Koštroman S., Graf W., Franević M., Posilović H. \& Waringer J. 2011b: Morphological and ecological features of Drusus larvae from the bosnicus group on the Balkan Peninsula with description of the larva of Drusus klapaleki Marinković-Gospodnetić, 1971. - Zoosymposia 5: 244-254.

Kučinić M., Previšić A., Graf W., Koštroman S., Lelo S., Šoufek M., ViteceK S. \& Waringer J. (in press): Larval description, molecular and ecological features of Drusus bosnicus (Klapálek, 1898) (Trichoptera: Limnephilidae) with note of distribution. - Zoosymposia.

Malicky H. 2004: Atlas of European Trichoptera. 2nd ed. Springer, Dordrecht, $359 \mathrm{pp}$.

MaLICKY H. 2005: Ein kommentiertes Verzeichnis der Köcherfliegen (Trichoptera) Europas und des Mediterrangebietes. Linzer Biol. Beitr. 37: 533-596.

MarinKović-Gospodnetić M. 1971a: The species of the genus Drusus in Yugoslavia. — Godišnjak Biol. Inst. Univ. Saraj. 24: 105-109.

MarinKović-Gospodnetić M. 1971b: New species of Trichoptera from Bosnia and Herzegovina. - Bull. Sci. (A) 16: 144-145.

MarinKović-Gospodnetić M. 1976: The differentiation of Drusus species of the group bosnicus. In Malicky H. (ed.): Proceedings of the First International Symposium on Trichoptera. Dr. W. Junk, The Hague, pp. 77-85.

MeIER L. \& Lim G.S. 2009: Conflict, convergent evolution, and the relative importance of immature and adult characters in endopterygote phylogenetics. - Annu. Rev. Entomol. 54: 85104.

Minoshima Y., Hayashi M., Kobayashi N. \& Yoshitomi H. 2013: Larval morphology and phylogenetic position of Horelophopsis hanseni Satô et Yoshitomi (Coleoptera, Hydrophilidae, Horelophopsinae). - Syst. Entomol. 38: 708-722.

Moog O., Graf W., JaneceK B. \& Ofenböck T. 2002: Inventory of "Sensitive Taxa" of Austrian Rivers and Streams. A valuable measure among the multimetric approaches and a tool for de- 
veloping a rapid field screening method to assess the ecological status of rivers and streams in Austria. In Moog O. (ed.): Fauna Aquatica Austriaca. 2nd ed. Bundesministerium für Land- und Forstwirtschaft, Wien, 4 pp.

MoretTi G.P. \& PIRISINU Q. 1981: Morphological characteristics of Leptodrusus budtzi Ulm. in the immature stages. In Moretti G.P. (ed.): Proceedings of the 3rd International Symposium on Trichoptera. Series Entomologica 20. Dr. W. Junk, The Hague, pp. 231-236.

OLÁH J. 2010: New species and new records of Palearctic Trichoptera in the material of the Hungarian Natural History Museum. - Annls. Hist.-Nat. Mus. Nat. Hung. 102: 65-117.

OlÁH J. 2011: New species and records of Balkan Trichoptera. Folia Hist. Nat. Mus. Matren. 35: 111-121.

OlÁH J. \& Kovács T. 2013: New species and new records of Balkan Trichoptera II. - Folia Hist. Nat. Mus. Matren. 37: 109-121.

Pauls S.U., Lumbsch H.T. \& Haase P. 2006: Phylogeography of the montane caddisfly Drusus discolor: Evidence for multiple refugia and periglacial survival. - Mol. Ecol. 15: 2153-2169.

Pauls S.U., Graf W., HaAse P., Lumbsch H.T. \& Waringer J. 2008: Grazers, shredders and filtering carnivores - The evolution of feeding ecology in Drusinae (Trichoptera: Limnephilidae): Insights from a molecular phylogeny. — Mol. Phylogenet. Evol. 46: 776-791

PITsch T. 1993: Zur Larvaltaxonomie, Faunistik und Ökologie mitteleuropäischer Fließwasser-Köcherfliegen (Insecta: Trichoptera). Landschaftsentwicklung und Umweltforschung. Schriftenreihe des Fachbereichs Landschaftsentwicklung, Sonderheft S8, Technische Universität Berlin, 316 pp.

Previšić A., Graf W., Vitecek S., Kučinić M., Bálint M., Keresztes L., Pauls S.U. \& Waringer J. 2014: Cryptic diversity of caddisflies in the Balkans: the curious case of Ecclisopteryx species (Trichoptera: Limnephilidae). - Arthr. Syst. Phylog. 72: 309-329.

Ronquist F., Teslenko M., van der Mark P., Ayres D., Darling A., Höhna S., Larget B., Liu L., Suchard M.A. \& HuelsenBECK J.P. 2012 : MrBayes 3.2: Efficient Bayesian phylogenetic inference and model choice across a large model space. - Syst. Biol. 61: 539-542.

Schmid F. 1956: La sous-famille des Drusinae (Trichoptera, Limnophilidae). - Mém. Inst. R. Sci. Nat. Belg. (Sér. 2) 55: 1-92.

SIPAHILER F. 2002: Hadimina torosensis, new genus and new species of Drusinae from southern Turkey (Trichoptera: Limnephilidae). - Nova Suppl. Entomol. 15: 239-248.

Statzner B. \& Higler B. 1985: Questions and comments on the River Continuum Concept. - Can. J. Fish. Aquat. Sci. 42: 1038-1044.

SzCZESNY B. 1978: Larvae of the subfamily Drusinae (Insecta: Trichoptera) from the Polish part of the Carpathian Mts. Acta Hydrobiol. 20: 35-53.

Tamura K., Peterson D., Peterson N., Stecher G., Nei M. \& KUMAR S. 2011: MEGA5: Molecular evolutionary genetics analysis using maximum likelihood, evolutionary distance, and maximum parsimony method. - Mol. Biol. Evol. 28: $2731-2739$

Ulmer G. 1920: Trichopteren und Ephemeropteren aus Höhlen. - Dt. Entomol. Z. 1920: 303-309.

Urbanič G., Waringer J. \& Graf W. 2003: The larva of Ecclisopteryx asterix Malicky, 1979 (Trichoptera: Limnephilidae: Drusinae). - Lauterbornia 46: 125-134.

VAN EMDEN F.L. 1957: The taxonomic significance of the characters of immature insects. - Annu. Rev. Entomol. 2: 91-106.

VIDELER J.J. 1995: Body surface adaptations to boundary-layer dynamics. - Symp. Soc. Exp. Biol. 49: 1-20.

Vieria-Lanero R., GonzÁlez M.A. \& Cobo F. 2005: The larva of Drusus bolivari (McLachlan, 1880) (Trichoptera: Limnephilidae: Drusinae). - Aquat. Insects 27: 85-93.
WARINGER J. 1985: The larva of Metanoea rhaetica Schmid, 1956 (Trichoptera: Limnephilidae: Drusinae) from a small Austrian mountain brook. - Aquat. Insects 7: 243-248.

WARINGER J. \& GRAF W. 2011: Atlas of Central European Trichoptera Larvae. Erik Mauch, Dinkelscherben, 468 pp.

WARINGER J., GRAF W. \& MAIER K.-J. 2000: The larva of Metanoea flavipennis Pictet, 1834 (Trichoptera: Limnephilidae: Drusinae). - Aquat. Insects 22: 66-70.

Waringer J., Graf W., Pauls S. \& Lubini V. 2007: The larva of Drusus nigrescens Meyer-Dür, 1875 (Trichoptera: Limnephilidae: Drusinae) with notes on its ecology, genetic differentiation and systematic position. - Ann. Limnol. 43: 161-166.

Waringer J., Graf W., Pauls S. \& Cianficconi F. 2008a: The larvae of Drusus improvisus McLachlan, 1884, Drusus camerinus Moretti, 1981 and Drusus aprutiensis Moretti, 1981 (Trichoptera: Limnephilidae: Drusinae). — Aquat. Insects 30: 269-279.

Waringer J., Graf W., Pauls S.U., Vicentini H. \& Lubini V. 2008b: DNA based association and description of the larval stage of Drusus melanchaetes McLachlan, 1876 (Trichoptera: Limnephilidae: Drusinae) with notes on ecology and zoogeography. - Limnologica 38: 34-42.

Waringer J., Graf W., Pauls S.U., Previšić A. \& Kučinić M. 2010: A larval key to the Drusinae species of Austria, Germany, Switzerland and the dinaric western Balkan. - Denisia 29: 383-406.

Waringer J., Graf W., Pitsch T., Pauls S.U., Previšić A. \& KuČINIĆ M. 2011: Description of the larval stage of Drusus mixtus (Pictet, 1834) (Trichoptera: Limnephilidae: Drusinae) with notes on its ecology and zoogeography. - Limnologica 41: 249-255.

Waringer J., Graf W., Bálint M., Kučinić M., Pauls S.U., Previšić A., Keresztes L. \& ViteceK S. 2013a: The larvae of Drusus franzressli Malicky 1974 and Drusus spelaeus (Ulmer 1920 (Trichoptera: Limnephilidae: Drusinae) with notes on ecology and zoogeography. - Zootaxa 3637: 1-16.

Waringer J., Graf W., Bálint M., Kučinić M., Pauls S.U., Previšić A., Keresztes L. \& ViteceK S. 2013b: The larva of Drusus vinconi Sipahiler, 1992 (Trichoptera, Limnephilidae, Drusinae). - ZooKeys 317: 69-80.

Wiggins G.B. 1998: Larvae of the North American Caddisfly Genera (Trichoptera). 2nd ed. University of Toronto Press, Toronto, $457 \mathrm{pp}$.

Zhou X., KJer K.M. \& Morse J.C. 2007: Associating larvae and adults of Chinese Hydropsychidae caddisflies (Insecta: Trichoptera) using DNA sequences. - J. N. Am. Benthol. Soc. 26: 719-742.

Received October 14, 2014; revised and accepted November 27, 2014 Prepublished online February 9, 2015

Supplementary files:

S1 (http://www.eje.cz/2015/037/S01.pdf). Specimen and sequence information for the data used in the present study.

S2 (http://www.eje.cz/2015/037/S02.pdf). Phylogenetic trees used for determining the larval associations of $D$. balcanicus, $D$. botosaneanui, D. serbicus, and D. tenellus. Shown are the $50 \%$ majority rule consensus trees based on $\mathrm{B} / \mathrm{MCMC}$ phylogenetic inferences for a) mitochondrial COI; b) mitochondrial LSU; c) nuclear WG; and d) nuclear CAD datasets. Posterior probabilities above 0.94 are shown on the supported nodes. The specimen level topology is shown for those taxa that were subject to life stage associations (highlighted in grey boxes; specimen codes as in supplementary file S1). Species-clades were collapsed for the other taxa for clarity. 